\title{
Halacarid mites (Acari: Halacaridae) from Esperance, Western Australia: Notes on taxonomy and faunal distribution of non-Copidognathinae
}

\author{
Ilse Bartsch \\ Deutsches Zentrum für Marine Biodiversitätsforschung, Forschungsinstitut Senckenberg, \\ Notkestr. 85, 22607 Hamburg, Germany, e-mail: bartsch@meeresforschung.de
}

\begin{abstract}
A recent survey on the halacarid fauna of Esperance (Western Australia) resulted in records of more than 40 species. The genera, and in parentheses the number of species, are: Actacarus (1), Agaue (4), Agauopsis (3), Arhodeoporus (2), Atelopsalis (1), Bradyagaue (1), Copidognathus (ca 13), Halacarellus (2), Halacaropsis (1), Halacarus (4), Lohmannella (2), Rhombognathus (5), Scaptognathus (1), Simognathus (3) and Werthella (1). In the present study the copidognathine genera Copidognathus and Werthella are excluded. Data on relevant taxonomic characters and distribution are given for 30 non-copidognathine species. Five species new to science are described; the species belong to the genera Agaue, Agauopsis, Arhodeoporus, Halacarus, and Scaptognathus. The diversity of non-copidognathine species collected from Esperance and its vicinity is distinctly lower than that collected on Rottnest Island (52 named non-copidognathines). Almost two-third (19 species) of the species from Esperance have also been taken in other areas of Australia, and about half of the species are known from Rottnest Island.
\end{abstract}

Key words: Western Australia, southern coast, Halacaridae, list of species, descriptions, biogeography

\section{INTRODUCTION}

In the past two decades there has been a considerable increase in knowledge of the Australian halacarid fauna, especially that of Western Australia. At present 28 species are known from tropical north-western Dampier and about 80 species from the warm-temperate western area, from Rottnest Island off Perth. In February 2003, the author had the opportunity to visit Esperance, which lies on the southern coast. First observations on the fauna and descriptions of species of the genera Agauopsis, Bradyagaue, Lohmannella, Rhombognathus, Simognathus and the copidognathine genus Werthella have been published recently (Bartsch 2004a, 2005b-e), and more follow in the present contribution. From the south-eastern and eastern coast of Australia, from Victoria, New South Wales and Queensland, slightly more than 100 species are recorded, but this number is incomplete, as that from the tropical Western Australia, as a large part of the halacarid fauna still is undescribed. World-wide more than 1000 marine halacarid species are known (Bartsch, 2004b).

\section{STUDY AREA AND METHODS}

Esperance, situated on the southern coast of Western Australia, at $33^{\circ} 51^{\prime} \mathrm{S}, 121^{\circ} 53^{\prime} \mathrm{E}$, lies in the temperate climate zone of Australia (Knox, 1963; $\mathrm{O}^{\prime}$ Hara and Poore, 2000). The water temperature in winter is about $13-15^{\circ} \mathrm{C}$, in summer around $22^{\circ} \mathrm{C}$ ( $\mathrm{Li}$ et al., 1999; Kendrick et al., 2005). The two major currents along Australia's southern coastline are the eastward flowing Leeuwin current, bringing warm water to Esperance from the western coast of Western Australia, and the westward flowing Flinders Current, transporting water masses from Victoria to Esperance (Middleton and Cirano, 2002; Cirano and Middleton, 2004). The coastline is exposed to almost continuous Southern Ocean swell and the wave action can be significant even in rather protected areas (Short, 2006). The coastline includes a moderate variety of habitats, long arcuate beaches with fine grained siliceous sand, rocky headland areas with cliffs, rocks and small bays with coarse, calcareous sediment, and patches of limestone reefs (Sanderson et al., 2000). There are no mangroves (Wells et al., 2005). Tides are semi-diurnal and the tidal range is generally less than $1 \mathrm{~m}$ (Short, 2006).

Various substrata, algae, seagrasses, colonial organisms and sediments, were collected from the tidal and shallow subtidal zone, some few samples are from depth of $10-40 \mathrm{~m}$. If not stated otherwise, the material was collected by the author. The meiofauna, including the mites, was extracted by washing the substrata. The mites were cleared in lactic acid and mounted in glycerine jelly. 
Holotypes, paratypes and voucher specimens are deposited in the Western Australian Museum, Perth (WAM), other slides in the Senckenberg Museum, Frankfurt (SMF) and the Zoological Institute and Zoological Museum, Hamburg (ZMH). Diagnostic data given to species are based on material from Esperance. Rare character states are in parentheses. Information on collection sites is restricted to new material, not studied and published before. To each species the known geographical distribution is given; the citation of the source of these data is restricted to references not mentioned in the preceding lines.

Abbreviations used in the descriptions are: $\mathrm{AD}=$ anterior dorsal plate; $\mathrm{AE}=$ anterior epimeral plate; ds- 1 to ds-5 = first to fifth pairs of dorsal setae numbered from anterior backward; GA = genitoanal plate; glp-1 to glp-5 = pair(s) of gland pores numbered 1 to 5 from anterior backward; $G O=$ genital opening; $G P=$ genital plate; $O C=$ ocular plate(s); P-2 to P-4 = second to fourth palpal segment(s); pas = parambulacral seta(e); $\mathrm{PD}=$ posterior dorsal plate; $\mathrm{PE}=$ posterior epimeral plate(s); pgs = perigenital setae; sgs = subgenital setae, sgs-1 to sgs-5 are numbered from anterior backward. The epimeral plates and legs, with their segments and claws, are numbered I to IV. The leg segments are trochanter, basifemur, telofemur, genu, tibia, and tarsus. The setation formula of the legs presents the number of setae from trochanter to tarsus. Unless stated otherwise the given number of setae of the tarsi includes the solenidion but excludes famulus and parambulacral setae. The position of a seta or gland pore is given in a decimal system with reference to the length of the relevant structure, from its anterior to posterior or basal to distal end.

\section{ANNOTATED LIST AND DESCRIPTION OF SPECIES}

The genera are arranged in an alphabetical order, not in subfamilies, as some, though not all of the present day subfamilies are not natural units. The subfamily of Copidognathinae, which is excluded from the present study, is based on a unique combination of characters with several synapomorphies. The characters are: $\mathrm{AE}$ of all instars with epimeral pores. Number of genital acetabula reduced, adults with no more than one pair of acetabula. Palps three- to four-segmented; one seta on $\mathrm{P}-2$, none on $\mathrm{P}-3$ (or in part representing P-3); one to three setae in basal whorl of P-4 (or in part representing $\mathrm{P}-4$ ). One pair of maxillary setae on rostrum, one pair (rarely more pairs) on gnathosomal base. Genua of all legs shorter than adjoining tibiae and telofemora. Genua I and II in general with four setae. Tibiae I and II with two to three ventral setae, tibiae III and IV with two ventral setae. Tarsus I with one to three ventral setae. Tarsi III and IV without ventral setae (except for that one of the parambulacral setae is moved to a ventral position). Solenidion on tarsus II in dorsolateral position. Paired claws distinct and present on all legs. Claw-like process of median sclerite minute. Trito- and deutonymphal instar reduced; no more than one nymph (the protonymph) during ontogeny. The subfamily of Copidognathinae includes the genera Acarothrix, Copidognathides, Copidognathus, Phacacarus, and Werthella. The non-copidognathine genera, treated below, have a character combination different from that just outlined.

\section{Genus Actacarus Schulz, 1937}

\section{Actacarus pacificus Bartsch, 1979}

Actacarus pacificus Bartsch, 1979a: 231-234, figures 1-14; Bartsch, 1993d: 75, 76, figure 1; Abé, 1997: 33-34, figure 2A-C; Bartsch, 2003d: 25-27, figure 2A-D.

Actacarus orthotectus Newell, 1984: 245-247, figures 705-707 (cf Bartsch, 1996a).

Actacarus marindicus Otto, 2000c: 116-119, figures 3a-e, 4a-e (cf Bartsch, 2003d).

\section{New Material}

Australia: Western Australia: 1 female, WAM T 78317, 1 male, WAM T 78318, Esperance, Lucky Bay, $33^{\circ} 59^{\prime} \mathrm{S}, 122^{\circ} 13^{\prime} \mathrm{E}$, shallow water sediment, 30$50 \mathrm{~cm}$ below low water line, 15 February 2003; 1 female, 1 male, $\mathrm{ZMH}$, collection data as above.

\section{Remarks}

Characters of $A$. pacificus are: length of female 259-263 $\mu \mathrm{m}$, of male 251-269 $\mu \mathrm{m}$; dorsal and ventral plates separate and delicately punctate; $\mathrm{OC}$ distinctly longer than wide; $\mathrm{AE}$ with four pairs of setae, PE with two ventral setae; ovipositor extending beyond anterior margin of $\mathrm{GA}$; integument of palps faintly punctate; $\mathrm{P}-4$ with short spux; tibia I with three apparently smooth ventral setae and tibiae III and IV each with a long, bipectinate seta.

Seven named species of Actacarus are known from Australia, the just mentioned $A$. pacificus, as well as $A$. australis Bartsch, 1993, A. chelonis Otto, 2000, A. cornutus Otto, 2000, A. festivus Bartsch, 2003, A. nanus Otto, 2000, and A. spinosus Otto, 2000 (Bartsch, 1993d, 2003d; Otto, 2000c). Actacarus pacificus, $A$. nanus and $A$. spinosus have four pairs of setae on the AE. Actacarus pacificus and $A$. nanus can be distinguished from the others by the size of the $O C$ and $A E$ and the ornamentation of $\mathrm{P}-2$. A. pacificus has elongate $\mathrm{OC}$ with a gland pore in the posterior third, the $\mathrm{AE}$ 
does not reach the level of the posterior setae of the $P E$, and the $\mathrm{P}-2$ are faintly punctate, in contrast the $\mathrm{OC}$ of $A$. nanus are short, the gland pore is almost in the middle of the plate, the AE extends almost to the level of the posterior setae of the PE and the insertion of leg IV, and the P-2 are coarsely punctate. Actacarus spinosus is characterized by its tibia I, with one of the ventral setae being coarsely bipectinate, and the P-4, with one of the setae thickened and bent.

\section{Distribution and ecology}

Western Australia (Esperance, Rottnest Island and Dampier), Hawaiian Island, Chile (Robinson Crusoe Island), Japan (Hokkaido). Present in intertidal and shallow subtidal $(10 \mathrm{~m})$ sandy deposits.

\section{Genus Agaue Lohmann, 1889}

\section{Agaue brevipes Bartsch, 1999 Figure 1A}

Agaue brevipes Bartsch, 1999c: 343-346, figures 6A$\mathrm{K}, 7 \mathrm{~A}-\mathrm{D}$.

\section{New Material}

Australia: Western Australia: 1 female, WAM T 78319, 1 male, WAM T 78320, Esperance, Duke of Orleans Bay, 335' $\mathrm{S}, 122^{\circ} 35^{\prime} \mathrm{E}$, seagrass (Posidonia sp.) from $0.5 \mathrm{~m}$ below water line, 10 February 2003; 1 female, ZMH, Esperance Bay, 3350'S, 121 ${ }^{\circ} 56^{\prime} \mathrm{E}, 11$ $\mathrm{m}$ depth, from Scaberia agardhii Greville (Phaeophyta), 11 February 2003.

\section{Remarks}

The length of the female idiosoma is $556 \mu \mathrm{m}$, of the male $390 \mu \mathrm{m}$, of the gnathosoma 200 and 195 $\mu \mathrm{m}$ respectively. The dorsal and epimeral plates bear smooth cerotegumental lamellae, such lamellae are present also on the telofemora, genua and tibiae, and on trochanters III and IV. The dorsal setae ds-2, $\mathrm{ds}-3$ and ds -4 are distinctly longer than ds -1 . The PE bears three dorsal setae anterior to leg III and one seta anterior to leg IV. In the female the GO is close to the anterior half of the GA, there is a ring of 18-21 setae around the GO, the ovipositor extends beyond the GO. In the male the GO is in the middle of the GA, and 21 and 76 pgs are in an inner and outer ring, respectively. The dorsal setae of $\mathrm{P}-2$ and P-3 are slender in both females and males. The number of setae on trochanter to tibia are on the legs I and II 1, 2, 5, 4, 11, on leg III 2, 2, 3, 4, 9 and on leg IV $0,2,3,3,8-9$.The length of all telofemora is less than three times the height, from telofemur I to IV the length equals 2.6-2.9, 2.3-2.4, 2.4-2.6 and 2.5-2.7 the height, respectively. Each of the paired claws bear a large accessory process. Tines of pectines are present on the accessory process and the shaft of claw, with a gap between (Figure 1A).

\section{Distribution and ecology}

Western Australia, Esperance and Rottnest Island. An epibiontic species, often present on seagrass or large algal fronds, in a depth range from 0.5 to $11 \mathrm{~m}$.

\section{Agaue similis sp. nov.}

Figure 1B-F, 2A-F

\section{Material examined}

\section{Holotype}

female, WAM T 78321, near Dempster Head, 335'S, 121⒌'E, Esperance, Western Australia, Australia, from moderately exposed lower tidal brown algae (Acrocarpia robusta (J. Agardh) Womersley), 9 February 2003.

\section{Paratype}

Australia: Western Australia: 1 female, $\mathrm{ZMH}$, collection data as above.

\section{Further material}

Australia: Western Australia: 1 male, WAM T 78322, Nine Mile Beach, $33^{\circ} 53^{\prime} \mathrm{S}, 121^{\circ} 47^{\prime} \mathrm{E}$, tufts of algae on wave-washed edge of limestone platform, 18 February 2003; 1 male, SMF, collection data as above.

\section{Etymology}

This species is extraordinarily similar (similis, Latin) in shape and chaetotaxy to the above mentioned A. brevipes.

\section{Diagnosis}

Length of female $480-495 \mu \mathrm{m}$, of male $470 \mu \mathrm{m}$. Cerotegumental lamellae of idiosoma small, smooth. AD and PD with pair of smooth lamellae indistinctly delimited. Pairs of ds-2, ds -3 and ds- 4 longer than ds- 1 and $d s-5$. Female perigenital setae close around GO, no setae near anterior margin of GA. PE with three dorsal setae anterior to insertions of legs III but none anterior to leg IV. Cerotegumental lamella of telofemora smooth, narrow. Dorsal seta on both P-2 and P-3 smooth in female and male. Claws with accessory process, pectines on accessory process and shaft with numerous tines.

\section{Description}

Female. Length $480-495 \mu \mathrm{m}$, length of holotype $492 \mu \mathrm{m}$, width $342 \mu \mathrm{m}$. Surface of dorsal plates almost smooth, cerotegumental lamellae small, crest-like. Length of AD $142 \mu \mathrm{m}$, width $157 \mu \mathrm{m}$; plate widest level with gland pores (Figure 1B), with parallel cerotegumental lamellae. Posterior margin truncate. Length of OC $84 \mu \mathrm{m}$, width 70 $\mu \mathrm{m}$; OC with two corneae; pore canaliculus 

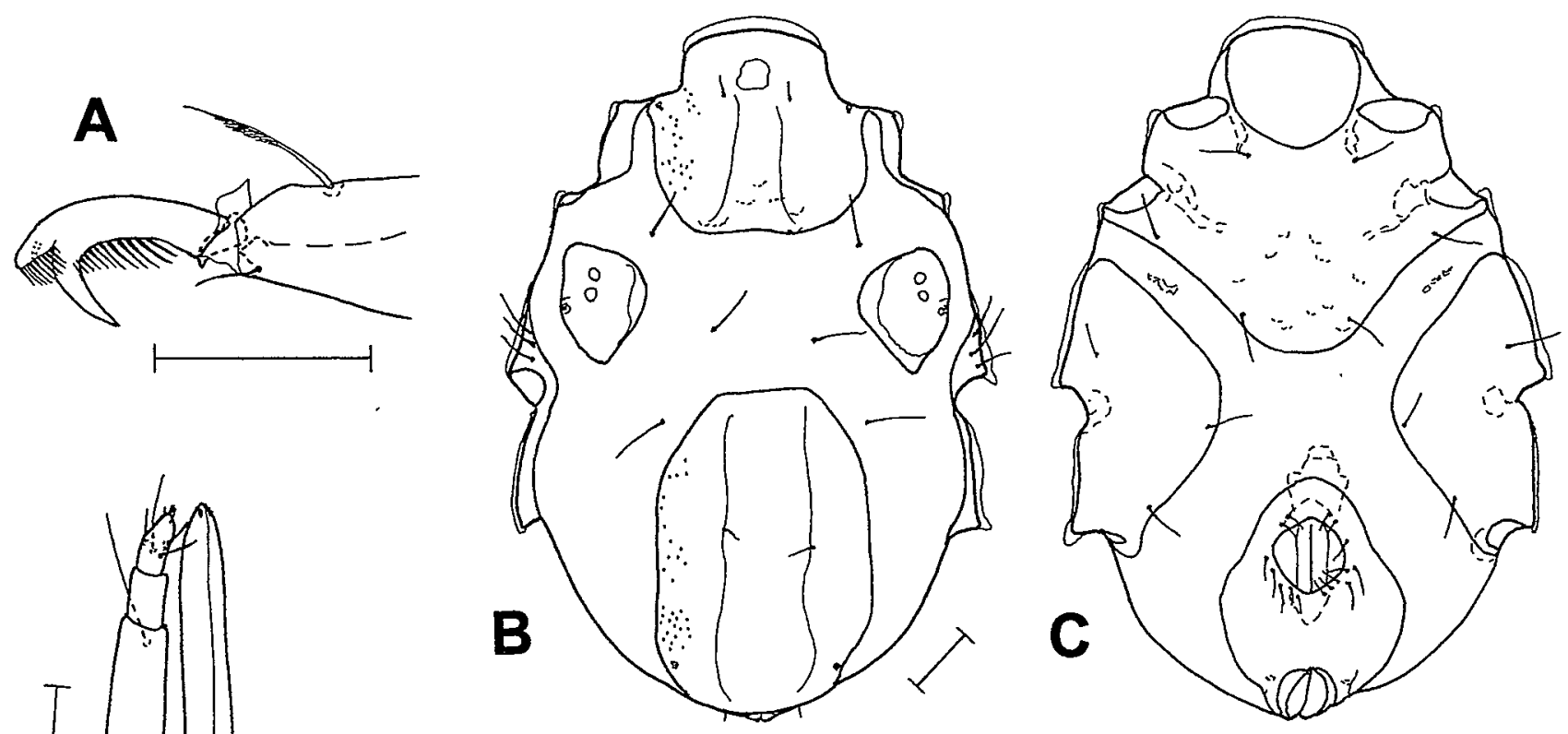

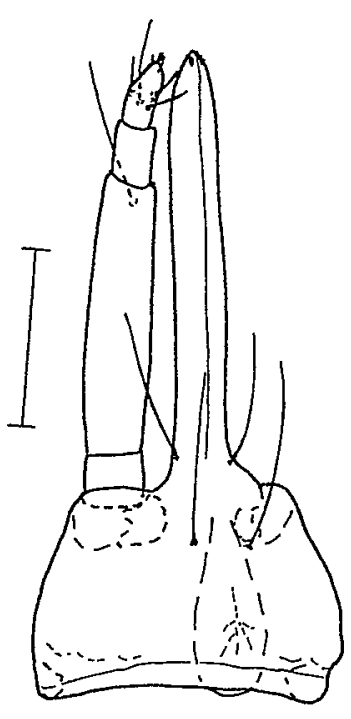

D

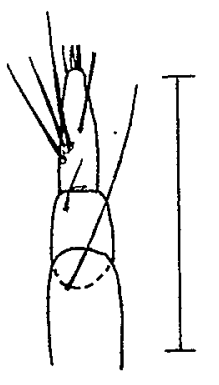

$\mathbf{E}$

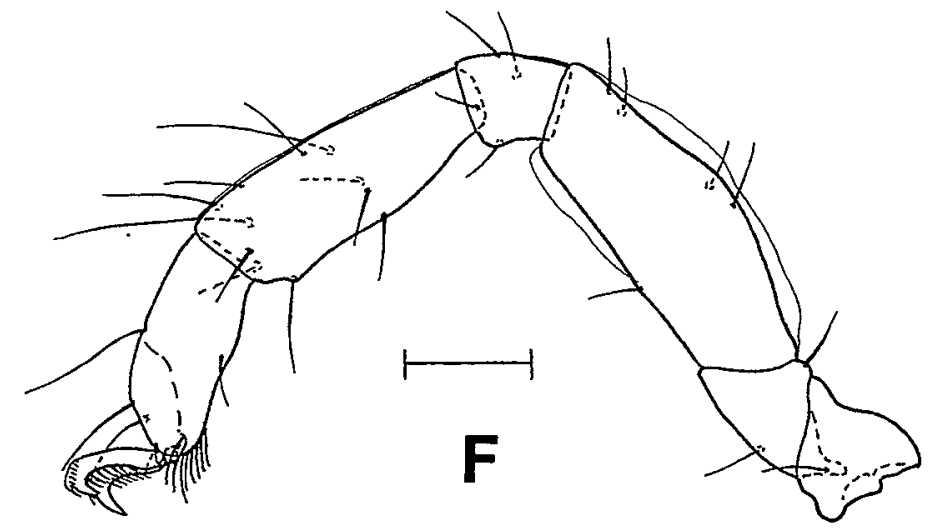

Figure 1 A. Agaue brevipes Bartsch, 1999, male, tip and one of claws of tarsus III, lateral. B-F. Agaue similis sp. nov., B, idiosoma, dorsal, female; C, idiosoma, ventral, female; D, gnathosoma, ventral, female; E, tip of palp, dorsal, male; F, leg I, medial, female. Scale $=50 \mu \mathrm{m}$.

immediately anterior to gland pore. Length of PD $230 \mu \mathrm{m}$, width $155 \mu \mathrm{m}$; anterior margin truncate. Pair of ds-1 small, on AD at the level of gland pores. Pairs of ds-2, ds-3 and ds- 4 in striated integument, longer than ds-1. Pair of ds-5 short, on PD.

Ventral plates smooth. Length of $\mathrm{AE} 144 \mu \mathrm{m}$, width $272 \mu \mathrm{m}$. With three pairs of ventral setae and distinct markings from muscle insertion (Figure 1C). PE with three dorsal setae anterior to insertion of leg III, three ventral setae but no dorsal seta anterior to insertion of leg IV. Length of PE $212 \mu \mathrm{m}$. Length of GA $167 \mu \mathrm{m}$, width $122 \mu \mathrm{m}$. Anterior margin rounded. With seven to nine pairs of perigenital setae close around GO. Length of GO 57 $\mu \mathrm{m}$. Distance between anterior margin of GA to that of $\mathrm{GO}$ about half length of GO.

Gnathosoma slender, almost twice as long as wide; length $174 \mu \mathrm{m}$, width $90 \mu \mathrm{m}$. Rostrum slender, more than twice the length of gnathosomal base (Figure 1D). Two pairs of maxillary setae almost equal-sized. Tectum with scaliform lamella. Palps extending to end of rostrum. P-4 hardly longer than P-3. As in male (Figure 1E) P-2 with long dorsal seta, P-3 with short, slender dorsal seta, P-4 with four setae, three in basal whorl and one in middle of segment; apex with two spurs and one setula.

Legs slender; leg I slightly shorter than leg IV. Telofemora of legs I and II longer than their tibiae, telofemora III and IV about as long as tibiae (Figures 1F, 2A-C). All telofemora and basifemora III and IV with smooth and narrow dorsal and ventral cerotegumental lamellae. Length:height ratio (without cerotegumental lamellae) of telofemora I-IV, 2.8, 2.3, 2.7, 2.8:1, respectively. Tarsi with large fossa membranes. Chaetotaxy of leg I, 1, 2, 5, 4, 11, 5 (cluster of eupathidia excluded); leg II, 1, 2, 4, 4, 10, 4 (cluster of eupathidia excluded); leg III, 2, 2, 3-4, 4, 9, 3; leg IV , 1, 2, 3, 3, 9, 3. Dorsal seta on both basifemur III and IV wide. Tibiae I and II each with two pairs of ventral setae; tibiae III and IV with four setae in line. Tarsi I to IV with three dorsal fossary setae, the two distal ones situated paired on fossa membranes. Lateral fossa 

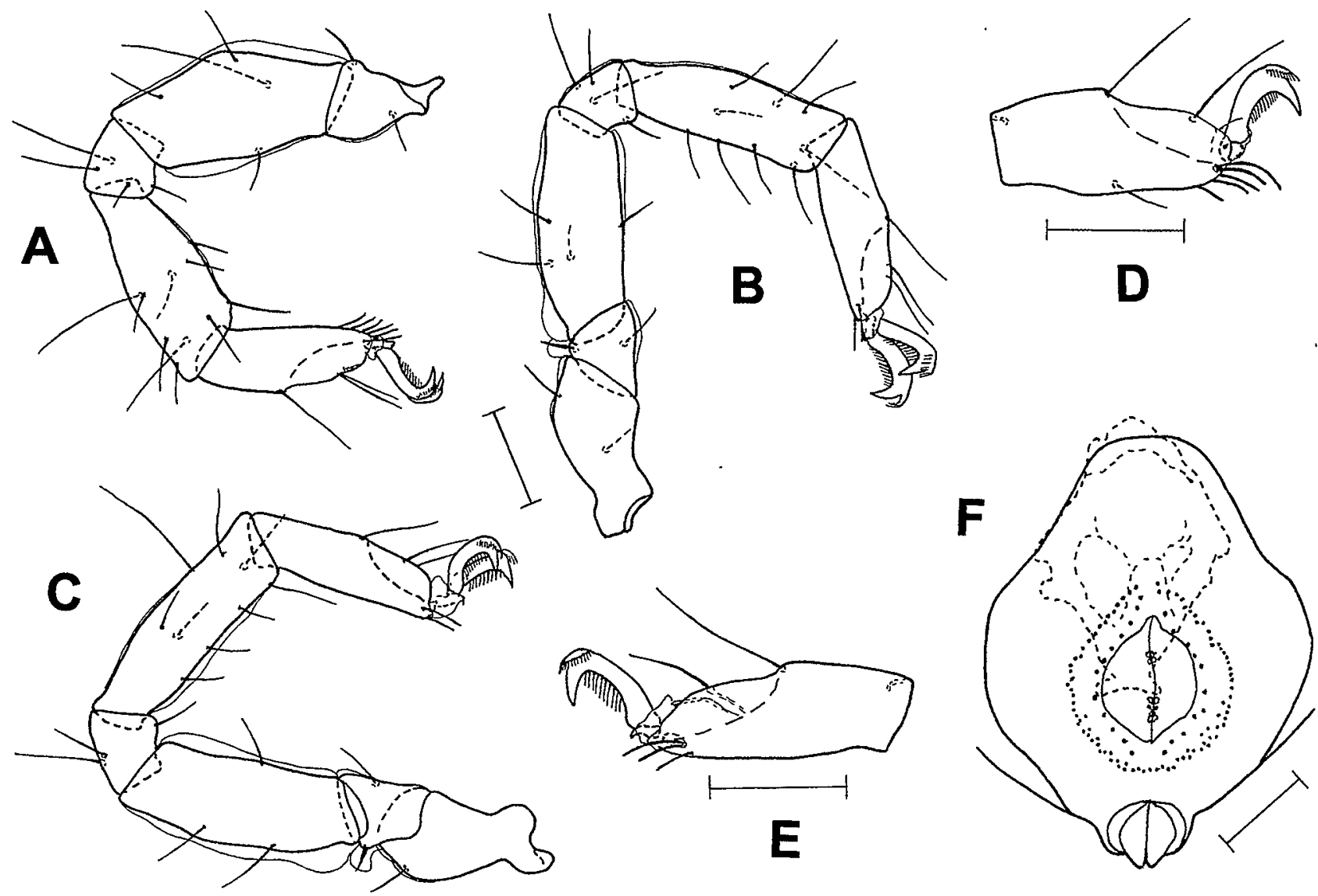

Figure 2 A-F. Agaue similis sp. nov., A, basifemur to tarsus II, medial, female; B, leg III, medial, female; C, leg IV, medial, female; D, tarsus I, lateral (medial setae and claw omitted), female; E, tarsus II, medial (lateral setae and claw omitted), female; $F$, genitoanal plate, male. Scale $=50 \mu \mathrm{m}$.

membrane of tarsus I with short solenidion $(15 \mu \mathrm{m})$ and afferent canal representing vestigial famulus (Figure 2D). Solenidion on tarsus II on medial membrane, $10 \mu \mathrm{m}$ long (Figure 2E). Tips of tarsi I and II with 12 and 6 eupathidia, respectively. Tips of tarsi III and IV each with pair of pas.

Paired claws with widened accessory process, this process with about 10 tines, shaft of claw with about 12 tines. Central sclerite with small tooth-like process.

Male. Length $470 \mu \mathrm{m}$. PD slightly larger than in female (relative to its size), in male $247 \mu \mathrm{m}$ long, $180 \mu \mathrm{m}$ wide. Plate extending further beyond ds- 4 than in female but not reaching level of ds-3. Genitoanal plate larger than in female, length 222 $\mu \mathrm{m}$, width $169 \mu \mathrm{m}$; length of GO $62 \mu \mathrm{m}$, width 50 $\mu \mathrm{m}$. Spermatopositor large, length $137 \mu \mathrm{m}$, width $97 \mu \mathrm{m}$, reaching to anterior truncate margin of GA. Distance from anterior margin of GO to that of GA 1.5 times length of GO. Perigenital setae arranged in two rings around GO, inner ring with 22 setae, outer ring with 90 setae (Figure 2F). Setae of inner ring apically splitted into three to four filaments; setae of outer ring seemingly more slender though at high magnification (oil immersion) slightly plumulose, too. Each genital sclerite with five sgs, sgs- 1 to sgs- 3 and sgs- 5 wide, sgs- 4 more slender, bristle-like. Gnathosoma as in female. P-2 and P-3 each with slender dorsal seta (Figure 1E). Legs as in female.

\section{Remarks}

Agaue similis is very similar to the Australian species A. brevipes and A. tenuipes Bartsch, 1999 (Bartsch, 1999c) in the shape of the idiosoma, gnathosoma and legs and the cerotegumental ornamentation but differs in that the PE lacks dorsal setae anterior to the insertion of leg IV and the accessory process on the claws only slightly extends beyond the arc of the claws.

The typical combination of characters of $A$. similis is: dorsal plates and legs with smooth cerotegumental lamellae; lamellae on AD parallel; $\mathrm{PE}$ with three dorsal setae anterior to insertion of leg III but none anterior to leg IV; in female distance between GO and anterior margin of GA somewhat. less than half length of GO, 7-9 pairs of pgs arranged close to $\mathrm{GO}$, none outlying; dorsal seta on both P-2 and P-3 smooth, tibiae cylindrical, not markedly club-shaped; claws with pectines. The Western Australian A. subglabra Bartsch, 1999 (Bartsch, 1999d) resembles A. similis, but 
discriminating character of $A$. subglabra are, the cerotegumental lamellae on the $\mathrm{AD}$ are in a gablelike arrangement, the distance from the GO to the margin of $\mathrm{GO}$ equals the length of $\mathrm{GO}$, the height of the dorsal cerotegumental lamellae of the telofemora is at least half that of the segment, and the claws bear minute tines on the shaft. Females of Agaue kurilensis Makarova, 1977 have, in contrast to $A$. similis, a larger number of pgs and the large $\mathrm{GO}$ is removed from the anterior margin of the GA. Agaue kurilensis is recorded from the coldtemperate Kurilen Islands (Makarova, 1977). In Agaue magellanica Newell, 1971 the cerotegumental lamellae on the $\mathrm{AD}$ form a gable; the interval between the anterior margin of $G O$ and $\mathrm{GA}$ is less and the claws and tines are more slender than in A. similis.

Agaue circellaris Bartsch, 1999, A. hamiltoni Womersley, 1937 and A. heterunguis Newell 1984 are known from their males only. The single record of Agaue circellaris is from Western Australia, those of $A$. hamiltoni and $A$. heterunguis from the west coast of Macquarie Island and from off Chile, respectively (Womersley, 1937; Newell, 1984; Bartsch, 1999c). Agaue circellaris can be easily separated from other species on the basis of its long gnathosoma, slender palps and the arrangement of setae on the $\mathrm{P}-4, A$. heterunguis because of its unusual claws, with few large tines but no accessory process, and absence of cerotegumental lamellae on the telofemora. The male GA of $A$. hamiltoni is much longer than in $A$. similis. The stated number of dorsal setae on the PE (two instead of three) of $A$. hamiltoni is probably an error.

Three setae on the PE anterior to the insertion of leg III are expected to be present in $A$. debilis (Lohmann, 1907), too. The illustration (Lohmann, 1907: figure 4,1) is said to represent a female, accordingly, the adult has unusual narrow dorsal plates, resembling those generally present in nymphs.

\section{Distribution and ecology}

Western Australia, Esperance. From wavewashed tufts of algae.

\section{Agaue subglabra Bartsch, 1999}

Figure 3A-E

Agaue subglabra Bartsch, 1999d: 184-187, figures 23-30.

\section{New Material}

Australia: Western Australia: 1 male, WAM T 78323, Esperance, New Island, $34^{\circ} 01^{\prime} \mathrm{S}, 122^{\circ} 13^{\prime} \mathrm{E}, 7$ $\mathrm{m}$ depth, from epiflora and fauna on Haliotis sp. (Gastropoda) (coll. A.F. Longbottom), 6 February 2003.

\section{Supplementary description}

Length of male idiosoma $470 \mu \mathrm{m}$, length of gnathosoma $197 \mu \mathrm{m}$. Cerotegumental lamellae on AD gable-like. Anterior cornea slightly larger than posterior one. Gland pore and pore canaliculus separated. PD rather narrow, its length $227 \mu \mathrm{m}$, width $150 \mu \mathrm{m}$; its pair of cerotegumental lamellae fused posteriorly. Pair of lamellae and anterior part of PD with faint foveate sculpturing (Figure 3A). Anal cone distinct. Pairs of ds-2, ds- 3 and ds -4 only slightly longer than ds- 1 and ds-5; ds- 4 in margin or just outside PD. Ventral plates with thin cerotegumental cover. PE with three dorsal setae anterior to insertion of leg III, two of these setae close to insertion of leg III, one seta close to anterior edge of $\mathrm{PE}$, distinctly removed from two following setae. No dorsal seta anterior to insertion of leg IV. Ventral setae on $\mathrm{AE}$ and PE short; anterior setae on $\mathrm{AE}$ inserted medial to internal apodemes (Figure 3B). Length of GA $192 \mu \mathrm{m}$, width $147 \mu \mathrm{m}$, length of GO $47 \mu \mathrm{m}$, width $37 \mu \mathrm{m}$. Spermatopositor $90 \mu \mathrm{m}$ long, $78 \mu \mathrm{m}$ wide. Distance from anterior margin of GO to that of GA equalling 1.4 times length of GO, distance from posterior margin of $\mathrm{GO}$ to end of anal cone 1.6 times length of GO. GO surrounded by slightly divaricate perigenital setae, 15 setae in an inner ring and about 50 in an outer ring (Figure 3C). Genital sclerites with five pairs of wide and flattened sgs. Gnathosoma slender; length of rostrum about twice that of gnathosomal base. Tectum scaliform. Setae on P-2 and P-3 slender (Figure 3D). Telofemora I to IV with dorsal cerotegument, height of lamellae about 0.35 of that of segment; ventral lamellae present in distal half. Tibiae without lamellae. Telofemora I to IV 3.0, 2.7, 2.4 and 2.6 times longer than high, respectively. Telofemora I and II longer than these legs' tibiae; telofemur IV almost as long as tibia IV. Chaetotaxy of trochanters to tibiae I to IV: legs I and II, 1, 2, 5, 4, 11, leg III, 2, 2, 3, 4, 8; leg IV, 0, 2, 3, 4, 8. Claws with accessory process apically and four to six very delicate tines on shaft (Figure 3E).

\section{Remarks}

The male resembles $A$. similis in that the idiosoma and legs have cerotegumental lamellae and the PE bears three dorsal setae anterior to the insertion of leg III but none anterior to leg IV, but the present male differs from that of $A$. similis on the basis of the rounded GA with a smaller number of perigenital setae (65 vs more than 100), smaller spermatopositor (not reaching anterior margin of GA vs reaching to or extending beyond that margin) and the claws (with few, very delicate tines vs numerous distinct tines).

Agaue subglabra was described from Rottnest Island on the basis of a single female (Bartsch, 1999d). The newly collected male from Esperance shares characters with the female $A$. subglabra such 
as shape of cerotegumental lamellae, size of $\mathrm{ds}-2$ to ds-4, arrangement of dorsal setae on PE anterior to insertion of leg III, length of gnathosoma, length relation of rostrum to gnathosomal base, and reduced claw pectines on the claws. The two individuals are considered to be conspecific.

\section{Distribution and ecology}

Western Australia, Esperance. Subtidal.

\section{Agaue tenuipes Bartsch, 1999}

Figure 3F

Agaue tenuipes Bartsch, 1999c: 341-343, figures 4AL, 5A-D.

\section{New Material}

Australia: Western Australia: 1 male, WAM T 78324, Esperance Bay, 335' $\mathrm{S}, 121^{\circ} 56^{\prime} \mathrm{E}, 11 \mathrm{~m}$ depth, from Scaberia agardhii Greville (Phaeophyta), 11 February 2003.

\section{Remarks}

This single male has a length of $556 \mu \mathrm{m}$, and the gnathosoma is $232 \mu \mathrm{m}$ long. The idiosoma and telofemora have smooth lamellae as described by Bartsch $(1999 \mathrm{c})$. The pairs of ds-2, ds-3 and ds-4 are longer than the $\mathrm{ds}-1$. The pore canaliculus on the $O C$ and the gland pore are immediately adjacent. The PE bears three dorsal setae anterior to leg III and one seta anterior to leg IV, the spermatopositor extends almost to the anterior margin of the ovate GA. The pgs are arranged around the GO, 74 in an outer and 23 in an inner ring, the setae in the inner ring are slightly plumose (oil immersion). The dorsal seta of both $\mathrm{P}-2$ and $\mathrm{P}-3$ is slender. The telofemora are slender, from leg I to IV 3.3, 2.9, 3.3 and 3.5 times longer than high. The number of setae, from the trochanter to tibia, of legs I and II are: $1,2,5,4,11$, of leg III: $2,2,3,4,9$, and of leg IV: $0,2,3,3,9$. On the claws the accessory process extends far beyond the arc; the claws bear J-shaped pectines (Figure 3F).

\section{Distribution and ecology}

Western Australia, Esperance and Rottnest Island. An epibiontic species, present from 1 to $11 \mathrm{~m}$ depth, amongst the epibios on seagrass and algal fronds.
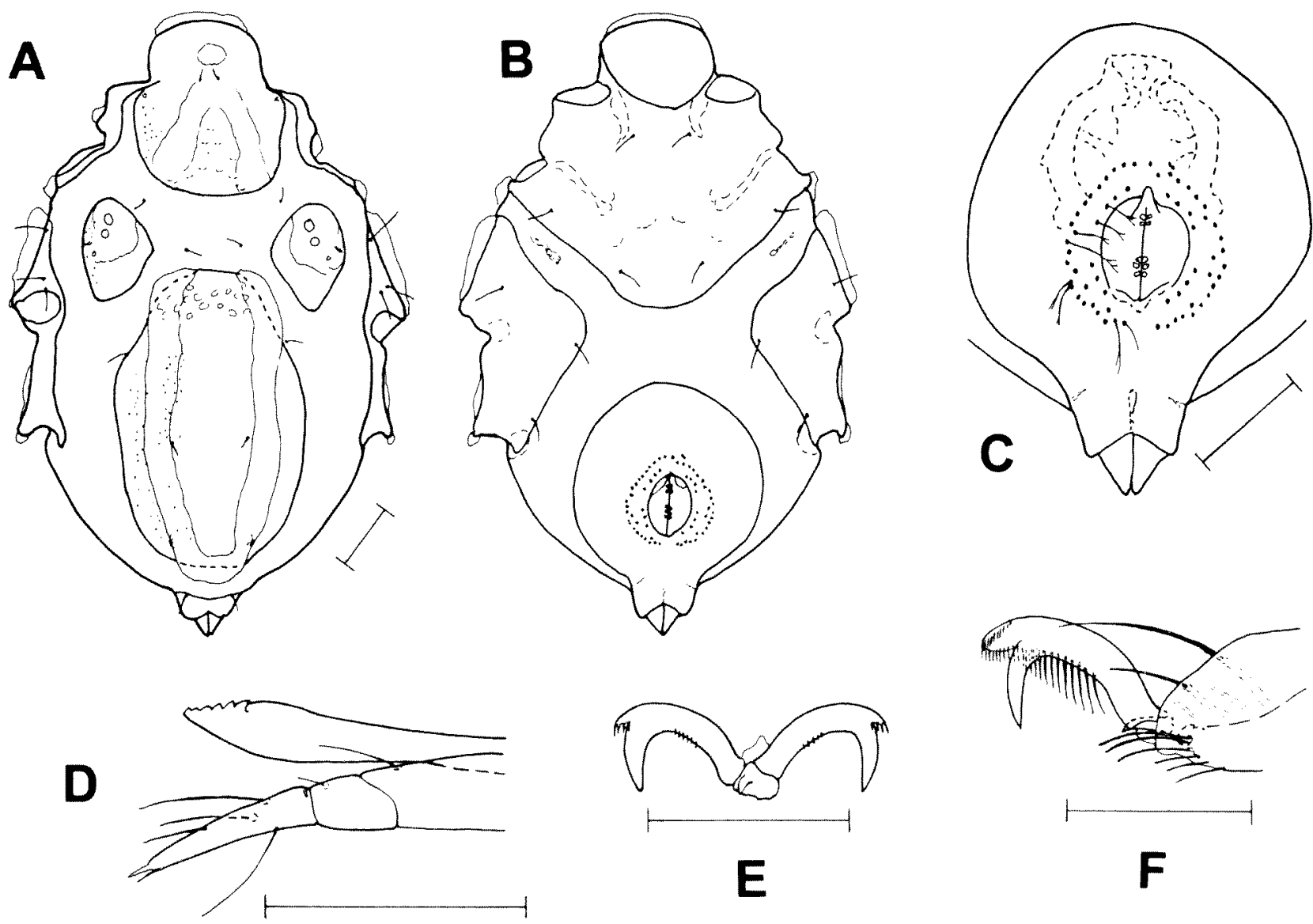

Figure 3 A-E. Agaue subglabra Bartsch, 1999, male, A, idiosoma, dorsal; B, idiosoma, ventral; C, genitoanal plate, ventral; D, tip of palp and chelicera; E, claws on tarsus III. F. Agaue tenuipes Bartsch, 1999, male, tip and one of claws of tarsus I, lateral. Scale $=50 \mu \mathrm{m}$. 
Genus Agauopsis Viets, 1927

Agauopsis calidictyota sp. nov.

Figure $4 \mathrm{~A}-\mathrm{I}$

\section{Material examined}

\section{Holotype}

male, WAM T 78325, Nine Mile Beach, 335's, $121^{\circ} 47^{\prime} \mathrm{E}$, Esperance, Western Australia, Australia, tufts of algae on wave-washed edge of limestone platform, 18 February 2003.

\section{Etymology}

The name is derived from the ornamental porose panels, from kalos (Greek), beautiful and diktyon (Greek), a net, a reticulum; diktyotos, reticulated.

\section{Diagnosis}

Length of male $275 \mu \mathrm{m}$, with small frontal spine. Member of the Agauopsis ornata group. PD with pair of panelled costae near lateral margin of plate; each panel with large procuticular alveolus and delicate surficial canaliculi. AE with paired, garland-like arranged porose panels. Rostrum shorter than gnathosomal base. Telofemur to tibia I with 3, 2, 3, 1 short, bluntly ending, denticulate spines. Ventral seta of tibia II spiniform, with delicate denticles, ventromedial seta short, slender and smooth.

\section{Description}

Male. Length of idiosoma $275 \mu \mathrm{m}$, width $165 \mu \mathrm{m}$. Idiosoma with small, triangular frontal spine. $A D$ and PD each with pair of costae, costae near lateral margins (Figure 4A). Integument of costae with porose panels. This panelling caused by procuticular alveoli, not by surficial reticulum. Alveoli, 2-4 $\mu \mathrm{m}$ in diameter, not opening to external via ostium but with six to eigth minute canaliculi. Integument outside porose panels with minute foveae, $1 \mu \mathrm{m}$ in diameter. Costae of $\mathrm{AD}$ extending from posterior margin anteriad to level of insertion of leg I; costae one to two such porose panels wide; slightly raised frontal spine with five porose polygons. Length of $\mathrm{AD} 107 \mu \mathrm{m}$, width 75 $\mu \mathrm{m}$; posterior margin truncate. Length of OC 65 $\mu \mathrm{m}$, width $42 \mu \mathrm{m}$; with two corneae, three to four porose polygons medial to corneae. Length of PD $145 \mu \mathrm{m}$, width $97 \mu \mathrm{m}$; costae U-shaped, fused posteriorly and extending to anterior margin of $\mathrm{PD}$; costae mostly two panels wide. Interval between costa and lateral margin of PD less than half that between costae. Pair of ds-1 on AD level with insertion of leg I. Pair of ds-2 on small sclerites in striated integument. Pair of ds-3 absent. Pairs of ds4 and ds- 5 on PD lateral to costae, ds -4 and ds- 5 level with insertion of legs III and IV, respectively.

Ventral plates with garland-like arranged porose panels (Figure 4B); outside porose panels integument with very delicate foveae (oil immersion). On AE each panel with 10-13 canaliculi at the surface and either one large or two to four small alveoli in procuticula; on GA four to five alveoli per panel. Length of AE $92 \mu \mathrm{m}$, width $154 \mu \mathrm{m}$. Porose areolae paired as illustrated; no unpaired areola in the median. Plate with three pairs of setae; epimeral slits not seen. Length of PE $119 \mu \mathrm{m}$; with one dorsal and three ventral setae. Length of GA $123 \mu \mathrm{m}$, width $95 \mu \mathrm{m}$; with porose panels along lateral margin and a pair of five to six panels just anterior to GO. Length of GO $38 \mu \mathrm{m}$, width $24 \mu \mathrm{m}$. Interval between GO and margin of GA equalling 1.5 times length of GO. GO surrounded by 25 wide, somewhat plumose pgs (Figure 4C) and one pair of smooth outlying setae. Genital sclerites with five pairs of subgenital setae, two anterior and two of posterior pairs short, setiform, middle pair of posterior setae spur-like.

Length of gnathosoma $67 \mu \mathrm{m}$, width $46 \mu \mathrm{m}$. Gnathosomal base marginally with porose panels (Figure 4D). Rostrum $27 \mu \mathrm{m}$ in length, hence shorter than gnathosomal base. Basal pair of maxillary setae on gnathosomal base, apical pair in posterior half of rostrum. Palps passing slightly beyond tip of rostrum. P-2 with dorsal seta; P-3 with medial spiniform seta; P-4 basally with one long and one short seta, apically with setula and two spiniform processes.

Leg I wider than following legs. Basifemur I with minute distoventral lamella (Figure 4E). Telofemur I with coarse reticulate sculpturing, polygons of lateral flank with small foveae. Sculpturing of telofemora II to IV present but less prominent than on leg I. Leg chaetotaxy (spines in roman numerals), leg I: 1, 2, 5+III, 3+II, 4+III, 6+I; leg II, 1, 2, 5, 4, 5, 5; leg III, 1, 2, 3, 3, 5, 3; leg IV, 0, 2, 3, 3, 5, 3. Spines of leg I short, with blunt, denticulate tip; two spines on genu I similar in size. Ventral seta of tibia II spiniform, with few delicate tines, ventromedial seta much more slender and apparently smooth (Figure 4F and I). Tibiae III (Figure 4G) and IV each with two stout ventral setae; ventrolateral seta larger than ventromedial seta and with very delicate denticles. Fossary setae of tarsus I wide and short; solenidion, $4 \mu \mathrm{m}$ in length, situated between lateral fossary seta and lamellar famulus (Figure 4H). Tip of tarsus I with pair of doubled pas; two small ventral setae not paired. Tarsus II with three short and wide fossary setae, a solenidion, $3 \mu \mathrm{m}$ in length, concealed by delicate dorsomedial fossary membrane, single ventral seta, and single blunt lateral pas (medial pas lacking) (Figure 4I). Tarsi III and IV with single medial pas but no lateral pas.

Paired claws of tarsus I smooth and somewhat smaller than those of following legs. Claws of tarsi II to IV with accessory process. At high magnification few minute tines recognizable on 

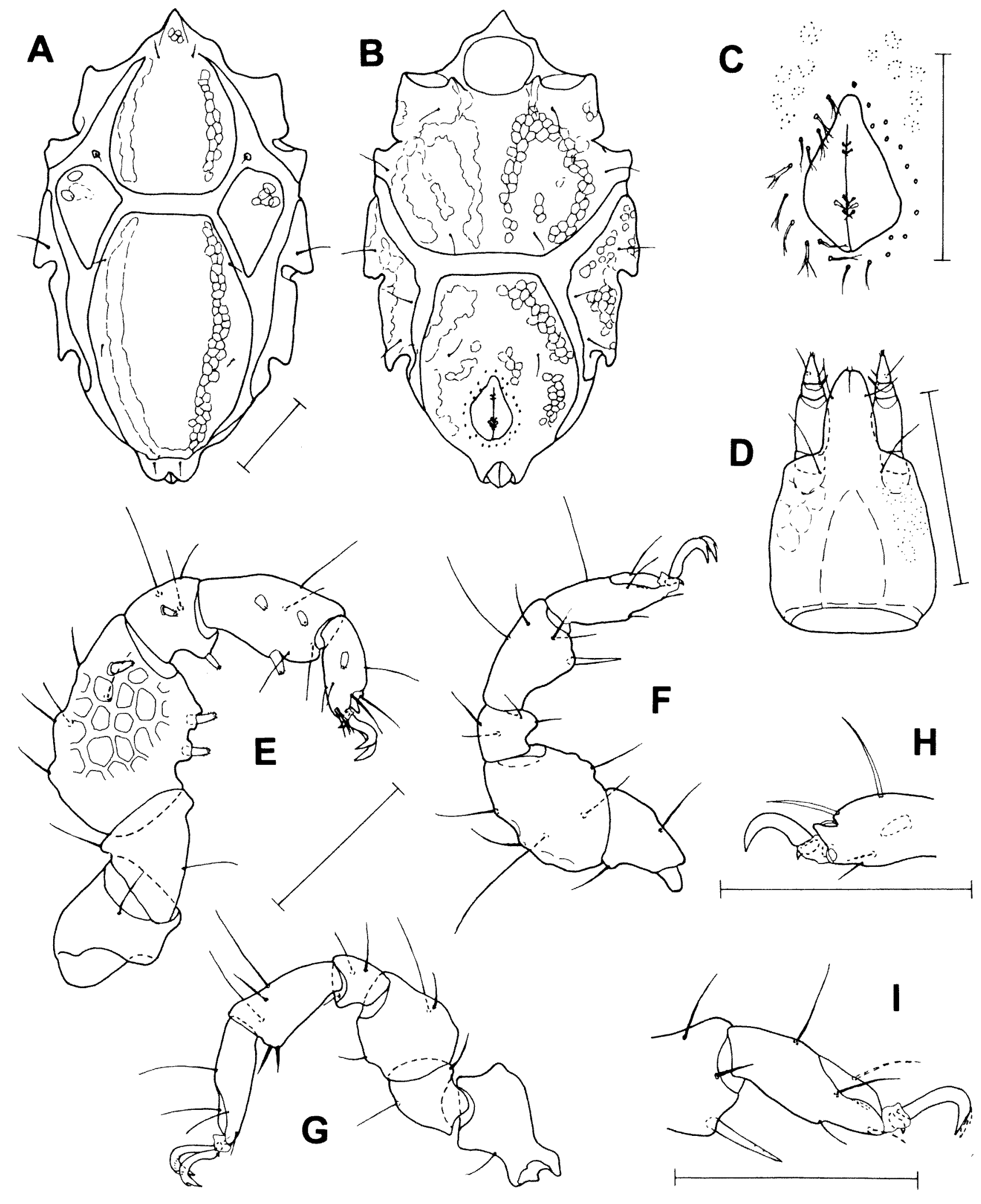

Figure 4 A-I. Agauopsis calidictyota sp. nov. male, A, idiosoma, dorsal; B, idiosoma, ventral; C, genital area; D, gnathosoma, ventral; E, leg I, medial; F, basifemur to tarsus II, medial; G, leg III, medial; H, tip of tarsus I, lateral (parambulacral setae, medial fossary seta and claw omitted); I, tibia and tarsus II, medial (lateral fossary seta, parambulacral seta and claw in broken line). Scale $=50 \mu \mathrm{m}$. 
inner flank of claw arc. Central sclerite on tarsus I with large ventral and minute apical tooth. Central sclerite of tarsi II to IV with ventral tooth only.

\section{Remarks}

Agauopsis calidictyota is a member of the $A$. ornata group, a group characterized by the garlandlike porose areolae on the AE (Bartsch, 1996b). Three species of this group have previously been recorded from Australia, $A$. decorata Otto, 1999, $A$. fenneri Otto, 1999 and $A$. ornatella Bartsch, 1996, with records from Queensland and Western Australia (Bartsch, 1996b, 2005c; Otto, 1999). The AE of $A$. calidictyota has no unpaired porose areola in the median, as present in $A$. decorata and $A$. fenneri. In contrast to $A$. ornatella the porose costae on $\mathrm{AD}$ and $\mathrm{PD}$ of $A$. calidictyota are wider, in general two panels wide, and there is no pair of ridges on the frontal spine.

Other species of the Agauopsis ornata group are: A. bacescui Konnert-Ionescu, 1977, A. bermudensis Bartsch and Iliffe, 1985, A. inflata Newell, 1984, A. nonornata Bartsch, 1999, A. ornata (Lohmann, 1893) and A. pseudoornata Bartsch, 1985, with records from the Indian, Atlantic and Pacific Ocean (Lohmann, 1893; Konnert-Ionescu, 1977, Newell, 1984; Bartsch, 1985, 1999b; Bartsch and Iliffe, 1985). Agauopsis bacescui has a combination of $3 / 1$ ventral/ventromedial spines on telofemur I whereas all the other species have the combination $2 / 1$ ventral/ventromedial spines. The porose costae on the PD of $A$. calidictyota are close to the lateral margins of the plate, the interval between costa and lateral margin of the PD is distinctly less than half that between the two costae (at the level of ds-5). A similar position of the costae is present in $A$. inflata, whereas in the other species, $A$. bermudensis, $A$. nonornata, $A$. ornata and $A$. pseudoornata, the PD is wider and the costae removed from the lateral margins. Agauopsis inflata can be separated from A. calidictyota on the basis of its truncate, rectangular frontal spine, a rostrum that is longer than the gnathosomal base, and the wide, bipectinate ventromedial seta on tibia II; in contrast, in $A$. calidictyota the frontal spine is spiniform, the rostrum shorter than the gnathosomal base and the ventromedial seta on tibia II slender and apparently smooth.

\section{Distribution and ecology}

Western Australia, Esperance. The only record is from tufts of algae from the wave-washed edge of a limestone platform.

\section{Agauopsis miliaris Bartsch, 2005}

Agauopsis miliaris Bartsch, 2005c: 346-349, figure $2 \mathrm{~A}-\mathrm{J}, 3 \mathrm{~A}-\mathrm{F}$.

\section{Remarks}

Agauopsis miliaris is a member of the $A$. microrhyncha group (Bartsch, 2005c), a group primarily characterized by its tibia I bearing one ventral and three ventromedial spines, the two basal ones being immediately adjacent. Four species are known from Australian shores, $A$. miliaris, $A$. australiensis Bartsch, 1996, A. mokari Otto, 1994, and A. narinosa Otto, 1994 (Otto, 1994, 1999; Bartsch, 1996b, 2005c).

From the small frontal spine to the anal cone the length of adult $A$. miliaris ranges from 399 to 426 $\mu \mathrm{m}$, the costae of the dorsal plates bear groups (polygons) with numerous canaliculi, the pair of gland pores on the PD is situated posterior to ds-4, the males have $46 \mathrm{pgs}$ (outlying setae included), the telofemur I bears three spines and the trochanters III and IV a small, rounded apical process. Agauopsis miliaris and $A$. australiensis (in parentheses) differ in their PD, with the ornamentation of its costae (with foveae and canaliculi) and the position of its anterior gland pores relative to the $\mathrm{ds}-4$ (anterior to $\mathrm{ds}-4$ ), the process on trochanters III and IV (large, triangular), and the number of male pgs (32-33 pgs).

Differences between $A$. miliaris and $A$. mokari are mentioned below. Agauopsis narinosa is characterized by its wide, flattened frontal spine and the ventral lamella on each of basifemora I and II, characters not present in the species from Esperance.

\section{Distribution and ecology}

Southern coast of Western Australia. Common on and amongst a variety of algae and seagrasses, from small, dense algal tufts, fronds of Scaberia sp. and Posidonia rhizoms. The records are from the water line to about $10 \mathrm{~m}$ depth.

\section{Agauopsis mokari Otto, 1994}

Agauopsis mokari Otto, 1994: 37-38, figures 9-16; Bartsch, 2005c: 350-351, figures 4A-G, 5A-D.

\section{Remarks}

This is another species of the Agauopsis microrhyncha group. In contrast to $A$. miliaris and the majority of species of this group, there are four spines on telofemur I. Deutonymphs can be identified on the basis of the three bipectinate setae on tibia II (instead of two bipectinate and one slender seta) and straight ventral margin of the tarsi III and IV, without any spiniform process. The length of adult $A$. mokari is $350-375 \mu \mathrm{m}$.

\section{Distribution and ecology}

Southern and south-eastern coast of Australia. Regular inhabitant of a variety of shallow water substrata. 
Genus Arhodeoporus Newell, 1947

\section{Arhodeoporus psammophilus Bartsch, 1993}

Arhodeoporus psammophilus Bartsch, 1993d: 8284 , figure $6 \mathrm{~A}-\mathrm{K}$

\section{New Material}

Australia: Western Australia: 1 female, WAM T 78326, 1 male, WAM T 78327, Esperance, Lucky Bay, $33^{\circ} 59^{\prime} \mathrm{S}, 122^{\circ} 13^{\prime} \mathrm{E}$, sediment from about $0.5 \mathrm{~m}$ depth, 9 February 2003; 1 male, ZMH, Esperance, Lucky Bay, sediment and small algae, $30 \mathrm{~cm}$ below low water line, 15 February 2003.

\section{Remarks}

Length of female $465 \mu \mathrm{m}$, of male $402-435 \mu \mathrm{m}$. The specimens are somewhat larger than the types from Rottnest Island. The dorsal and ventral plates are uniformly and delicately punctate; the $O C$ are long and extend beyond the insertion of leg IV; in the anterior part of the $\mathrm{OC}$ there is one distinct and one faintly delimited comea. The gnathosomal base bears punctate areolae. One of the two ventromedial setae on the tibia $I$ is short and delicately bipectinate; the tibia II bears two bipectinate setae, and each of the tibiae III and IV one such seta.

Arhodeoporus psammophilus as well as the eastern Australian species A. caudatus Otto, 2000, A. clypeatus Otto, 2000, A. corallicolus Otto, 2000, and $A$. lizardensis Otto, 2000, the Philippine $A$. mactanus Bartsch, 1991, and the eastern African species A. longirostris Bartsch, 1981 (Bartsch 1981, 1991; Otto, 2000d) are extraordinarily similar in their shape. Arhodeoporus psammophilus comes close to A. corallicolus. According to Otto $(2000 \mathrm{~d})$, the most marked differences are (1) A. corallicolus has only one distinct cornea on the $O C$ and (2) the punctation of the ventral plates is not uniform, that of on the AE is more coarse than on the other plates. The variability of these characters and a possible effect of mounting and mounting medium is not known.

\section{Distribution and ecology}

Records of Arhodeoporus psammophilus are from Western Australia, from Rottnest Island and Esperance. The species is psammophilous.

\section{Arhodeoporus robustus sp. nov.}

Figure $5 \mathrm{~A}-\mathrm{K}$

\section{Material examined}

\section{Holotype}

male, WAM T 78328, Duke of Orleans Bav, 3355 ' $12235 \mathrm{E}$, Esperance, Western Australia, Australia, on rock with tufts of small algae and amounts of debris, low tide area, 19 february 2003.

\section{Etymology}

This species is more robust than the similar looking Arhodeoporus disparilis Bartsch, 1997 , hence the name robustus from robustus (Latin), strong, robust.

\section{Diagnosis}

Length of male $242 \mu \mathrm{m}$. Member of the Arhodeoporus bonairensis group. Dorsal plates with porose costae, remainder with small pits. PD with pair of costae and scattered marginal porose panels. AE and GA in males fused. Ventral plates with distinctly demarcated porose areolae. Area of AE with three pairs of porose areolae, GA with pair of minute lateral porose areolae. Tibiae I to IV ventrally with $0,2,1,0$ bipectinate and 4, 1, 1, 2 smooth setae. Claws with accessory process and minute tines.

\section{Description}

Male. Length of idiosoma $242 \mu \mathrm{m}$, width $133 \mu \mathrm{m}$. Dorsal plates with slightly raised areolae (Figure $5 \mathrm{~A}$ ), remainder of plate with scattered small pits (Figure 5C). Raised areolae with porose panels, each panel with 7-12 canaliculi (Figure 5C), integument immediately around porose areolae smooth. AD with small truncate frontal lamella. Length of $\mathrm{AD}$ $75 \mu \mathrm{m}$, width $62 \mu \mathrm{m}$. Raised area in shape of an inverted wine-glass, with an anterior and pair of posterior porose areolae, 12 and $20 \mu \mathrm{m}$ in length, respectively; raised area between porose panels distinctly foveate, ovate pits 2-3 $\mu \mathrm{m}$ long. Length of OC $82 \mu \mathrm{m}$, width $25 \mu \mathrm{m}$; its tail-like posterior end extending halfway between insertions of legs III and IV. A small porose areola medial to two corneae, gland pore and pore canaliculus lateral to posterior cornea. Length of PD $162 \mu \mathrm{m}$, width $100 \mu \mathrm{m}$; anterior margin wide, truncate. Medial pair of costae almost parallel; scattered porose panels in lateral margins immediately anterior and somewhat posterior to level of insertion of leg IV. Dorsal setae small, ds- 1 on AD in about middle of plate, $d s-2$ in anteromedial margin of $O C, d s-3$ to ds -5 on PD, ds3 near anterior margin, ds-4 and $\mathrm{ds}-5$ immediately lateral to costae, ds-4 halfway between ds-3 and ds5. Pair of ds-6 on anal plate.

Ventral plates with demarcated areolae (Figure $5 B$ ) with porose panels, remainder of plates with pits, these pits distinct just posterior to camerostome and between $\mathrm{GO}$ and anal sclerites but vestigial in remainder of plates. AE and GA fused to a ventral shield; length of shield $229 \mu \mathrm{m}$, width $108 \mathrm{\mu m}$. Area of $\mathrm{AE}$ with marginal porose panels between insertion of legs $I$ and II, a minute porose panel posterior to insertion of leg II, and a third pair of porose panels in posterior part of plate. Area of $A E$ with pair of epimeral pores and three pairs of slender ventral setae. Length of PE $120 \mu \mathrm{m}$. Marginal porose panels anterior to insertions of legs 

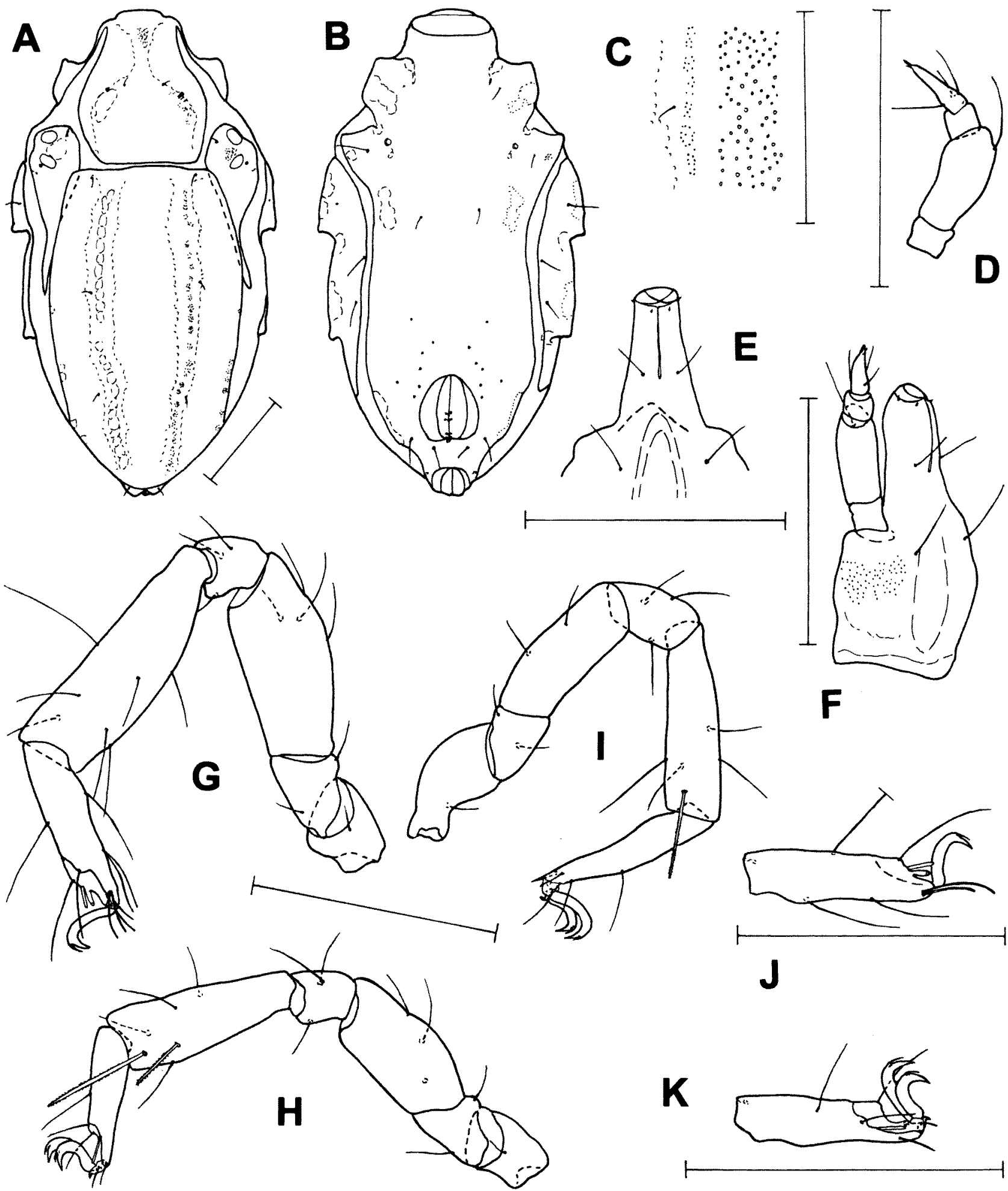

$\perp$

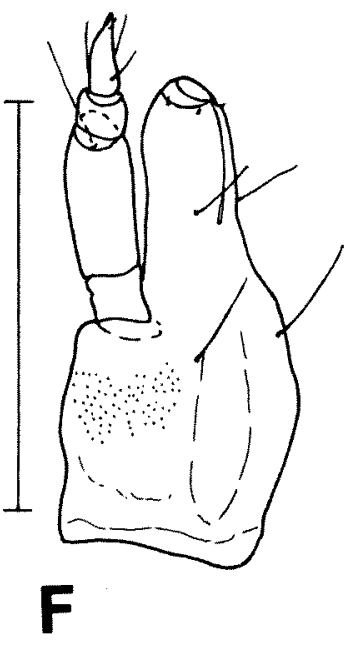

Figure 5 A-K. Arhodeoporus robustus sp. nov., male, A, idiosoma, dorsal; B, idiosoma, ventral; C, portion of PD at the level of left ds-4; D, palp, lateral; E, rostrum and adjacent gnathosomal base, ventral; $\mathrm{F}$, gnathosoma, ventrolateral; G, leg I, medial; H, leg II, medial; I, leg III, medial; J, tarsus I, lateral (medial setae and claw omitted); $\mathrm{K}$, tarsus II, dorsomedial. Scale $=50 \mu \mathrm{m}$.

III and IV. Area of GA with pair of small porose areolae lateral to GO. Length of GO $32 \mu \mathrm{m}$, width $30 \mu \mathrm{m}$. With nine pairs of pgs. Genital sclerites with five pairs of minute pgs, two anterior and three posterior ones. A pair of small internal genital acetabula shining through genital sclerites.
Gnathosoma short, length $60 \mu \mathrm{m}$, width $36 \mu \mathrm{m}$. Gnathosomal base with five to six marginal porose panels (Figure 5F). One pair of maxillary setae on gnathosomal base, one pair on rostrum. Tip of rostrum with two pairs of tiny rostral setae and a pair of spiniform lamellae. Rostral sulcus extending 
just beyond rostral pair of maxillary setae. Triangular tectum short (Figure 5E). Palps slender, extending beyond tip of rostrum. P-2 with dorsal seta; $\mathrm{P}-4$ with three setae in basal whorl

Legs slender. Telofemora shorter than corresponding tibiae. Length:height ratio of telofemur I 2.4:1. Integument delicately foveate. Leg chaetotaxy: $\operatorname{leg} I, 1,2,4,3,7,7 ; \operatorname{leg}$ II, 1, 2, 3, 3, 6, 4; $\operatorname{leg}$ III, 1, 2, 2, 3, 5, 3; $\operatorname{leg}$ IV, 0, 2, 2, 3, 5, 3. Four ventral setae on tibia I slender, smooth (Figure 5G). On tibia II ventral seta slender and smooth, two ventromedial setae bipectinate, the apical one distinctly longer than the basal seta (Figure $5 \mathrm{H}$ ). On tibia III ventral seta slender and smooth, ventromedial seta bipectinate (Figure 5I), and on tibia IV both setae smooth. Tarsus I with pair of doubled pas; both solenidion, $6 \mathrm{\mu m}$ long, and famulus, $3 \mu \mathrm{m}$ long, on dorsolateral fossa membrane (Figure 5J). Tarsus II with eupathid singlets and dorsomedial solenidion (Figure $5 \mathrm{~K}$ ); on tarsus III medial pas slender, lateral pas widened; on tarsus IV both medial and lateral pas widened.

Claws of tarsi apically with accessory process and delicate tines. No tines on shaft of claw. Central sclerite with minute claw-like process.

\section{Remarks}

Arhodeoporus robustus belongs to the $A$. bonairensis group, a group characterized by an AD with a raised area in the shape of an inverted wineglass; both this area and the longitudinal costae on the PD bear porose panels. The ventral plates have demarcated porose panels; two or more of the ventral plates are fused. Arhodeoporus robustus is extraordinarily similar to A. disparilis Bartsch, 1997 known from Rottnest Island, Western Australian (Bartsch, 1997); A. robustus is larger than $A$. disparilis ( 242 vs $200 \mu \mathrm{m}$ ), the porose panels on the dorsal and ventral plates and the anterior part of the PD are wider (cf. Figure $5 \mathrm{~A}$ and $\mathrm{B}$ vs Bartsch, 1997: figures 13 and 14), the dorsal plates outside the costae bear delicate foveae (vs reticulate), the costae on the PD are in an almost parallel arrangement (vs divergent), and the $\mathrm{ds}-4$ are halfway between the ds-3 and ds -5 (vs close to the ds-3). Unfortunately only one male of each species is available for study and it cannot be excluded that the just mentioned differences represent extremities in a series of variants.

Other species of the Arhodeoporus bonairensis group are A. bonairensis Viets, 1936, A. thyreophorus André, 1959 and A. ventromaculatus Otto, 2000. In these species the adults have the ventral plates $A E, G A$ and $P E$ fused to a ventral shield.

\section{Distribution and ecology}

Western Australia, Esperance, from tufts of small algae (corallines) growing at the low tide edge. All present records of representatives of the Arhodeoporus bonairensis group are from shallow water in tropical and warm-temperate areas (Viets, 1936; Newell, 1947; André, 1959; Bartsch, 1977C, 1997; Sarma \& Chatterjee, 1993b; Otto, 2000d).

\section{Genus Atelopsalis Trouessart, 1896}

\section{Atelopsalis pacifica Bartsch, 1985 Figure 6A-D}

Atelopsalis pacifica Bartsch, 1985: 272-275, figures 12-23; Sarma \& Chatterjee, 1993a: 117-119, figures $1-5$.

\section{New Material}

Australia: Western Australia: 1 male, WAM T 78329, Esperance, Duke of Orleans Bay, 33⒌' $\mathrm{S}$, $122^{\circ} 35^{\prime} \mathrm{E}$, demosponge with rich epi- and endofauna, just below low water edge, 19 February 2003.

\section{Remarks}

The length of the single available male is $198 \mu \mathrm{m}$. The AD bears a gable-shaped costa, the PD a pair of costae (Figure 6A), the remainder of the plates is reticulate, the polygons are in turn subdivided. Each of the rosette pores within the costae is reduced to a small ostium with a slightly larger alveolus; the canaliculi are lacking. The ventral plates have demarcated porose areolae (Figure 6B) with pores similar to those on the costae of the dorsal plates; the ventral parts of the plates are smooth, the marginal parts foveate. On the AE there are two porose areolae plus a single pore at the level of the epimeral vesicles, on the PE two marginal areolae and one ventral porose areola and on the GA a pair of porose areolae lateral to the GO. Leg I is much wider than the following legs. Tibia I bears a pair of short mid-segmental spines and, near the end of the segment, a pair of ventral setae (Figure 6C). The surface of telofemur I is coarsely sculptured, reticulate, with a pair of cuticular spines. The tibiae II (Figure 6D), III and IV each bear a bipectinate ventral seta, and the tarsi II to IV $4,4,3$ dorsal setae, respectively. The tarsi end with a pair of claws and a minute claw-like median sclerite. The paired claws of all tarsi are similar in size, they bear an accessory process and on the tarsi II to IV pectines with minute tines.

In contrast to the holotype collected on Mactan Island, the Phillippines (Bartsch, 1985), the present specimen has fewer rosette pores; the porose areolae on the ventral plates are smaller. But obviously, as demonstrated by Bartsch (1985: figures 12 and 23) in presenting the dorsal aspect of two specimens, the number of rosette pores is variable.

A female from Rottnest Island (Duck Rock, 7-10 

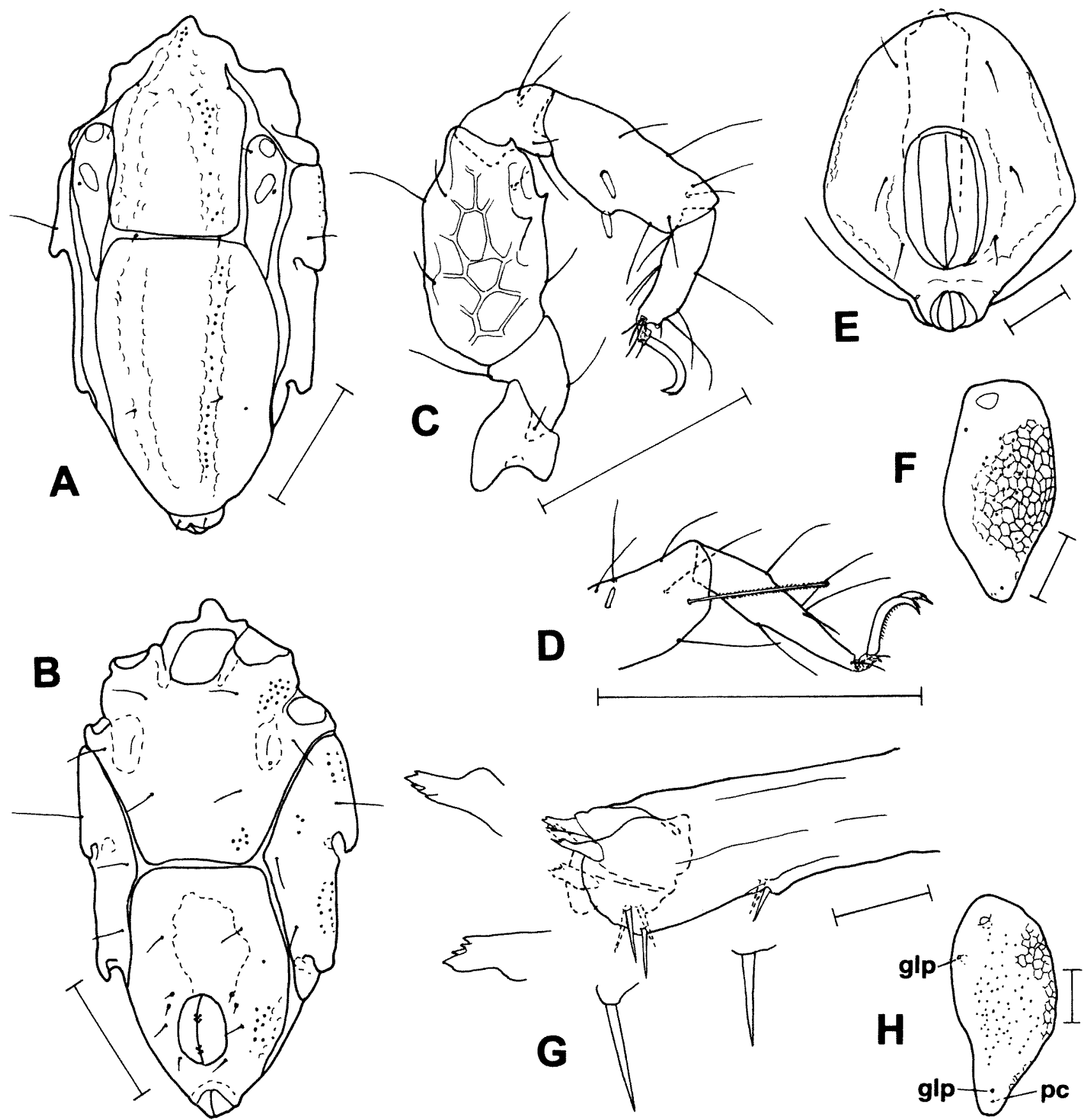

Figure 6 A-D. Atelopsalis pacifica Bartsch, 1985, male, A, idiosoma, dorsal; B, idiosoma, ventral; C, leg I, medial; D, tibia and tarsus II, medial. E and F. Halacarellus lubricus Bartsch, 1985, female, E, genitoanal plate, ventral; F, ocular plate. $\mathrm{G}$ and $\mathrm{H}$. Halacarellus rottnestensis Bartsch, 1999, female, G, ovipositor with genital spines (enlarged) (genital spines of opposite side in broken line); $\mathrm{H}$, ocular plate. ( $\mathrm{glp}=$ gland pore; $\mathrm{pc}=$ pore canaliculus) Scale $=50 \mu \mathrm{m}$.

m depth, 9 January 1991), has a length of $197 \mu \mathrm{m}$. The arrangement of the pores on the dorsal plates is similar to that of the holotype from the Philippines.

\section{Distribution and ecology}

Records of Atelopsalis pacifica are from the Philippines (Sulu Sea), India (Bay of Bengal), and Western Australia, from Rottnest Island (Indian Ocean, new record) and Esperance (Southern Ocean).

\section{Genus Bradyagaue Newell, 1971}

\section{Bradyagaue exilis Bartsch, 2004}

Bradyagaue exilis Bartsch, 2004a: 66-68, figures 116.

\section{Remarks}

Length $730 \mu \mathrm{m}$. The most obvious character of $B$. exilis is the anteriorly ovate, lobe-like idiosoma that extends beyond the camerostome. Most of the 
Bradyagaue species have an anteriorly broadly arched or truncate idiosoma, exceptions are $B$. medialis Newell, 1984 and B. scutella Bartsch, 1992 which have a frontal lobe similar to that of $B$. exilis. Bradyagaue medialis is known from south-eastern Africa, B. scutella from Rotnest Island, Western Australia (Newell, 1984; Bartsch, 1992b). Bradyagaue exilis can be distinguished from these two species by the position of ds- 3 , on the OC in $B$. exilis, but in the striated integument in $B$. medialis and B. scutella.

\section{Distribution and ecology}

Western Australia, Esperance. The only record is from the Esperance Bay, extracted from fronds of Scaberia (Phaeophyta), from $11 \mathrm{~m}$ depth.

\section{Genus Halacarellus Viets 1927}

\section{Halacarellus lubricus Bartsch, 1986 Figure $6 \mathrm{E}$ and $\mathrm{F}$}

Halacarellus lubricus Bartsch, 1986: 552-553, figures 24-34; Otto, 1994: 41-43, figures 25-33.

\section{New Material}

Australia: Western Australia: 1 female, 1 male, WAM T 78330, Esperance, Lucky Bay, 3359'S, $122^{\circ} 13^{\prime} \mathrm{E}$, algal scrub on rocks, just below water line; 13 February 2003; 1 female, 1 deutonymph, $\mathrm{ZMH}$, collection data as above; 1 male, SMF, Esperance, Duke of Orleans Bay, 33 $55^{\prime} \mathrm{S}, 122^{\circ} 35^{\prime} \mathrm{E}$, demosponge with epiflora, low water line, 17 February 2003.

\section{Remarks}

Length of the female $490-549 \mu \mathrm{m}$, of the male 491-525 $\mu \mathrm{m}$. The dorsal plates have panelled reticulate areolae distinctly delimited from slightly raised areas with almost smooth integument. Delicate canaliculi are present in the integument but may be obscured by the panelling. The two gland pores of the $O C$ are widely separated, the posterior one is in the distal corner of the plate followed by the pore canaliculus (Figure 6F). The pair of gland pores on the PD is at 0.65 . The female GA bears three pairs of pgs; the ovipositor (in rest) extends to or slightly beyond the anterior margin of GA (Figure 6E). The telofemora I to IV are 2.3, 2.0, 2.4, 2.3 times longer than high; the genua III and IV 1.8 times longer than high. From trochanter to tibia the number of setae of leg I is: 1, 2, 4, 5, 13, of leg II: 1 , $2,5,5,11$, of leg III: $2,3,3,4,6$, and of leg IV: $0,3,3$, 3,6 .

Specimens from New South Wales have four to seven pgs on either side of the GA (Otto, 1994: 41)

Halacarellus lubricus is similar to $H$. rotmestensis Bartsch, 1999 and H. katewilsonae Otto, 2001, both species are recorded from Australia (Bartsch, 1999c;
Otto, 2001). Discriminating characters are discussed below.

\section{Distribution and ecology}

Australia, Western Australia and New South Wales, and New Zealand, North Island. All records are from scrub-like algal formations, mostly from corallines. One specimen was intensely fouled with suctorians (Protozoa: Suctoria), which were fixed to the gnathosoma, legs (from trochanter to tarsus) and idiosoma.

\section{Halacarellus rottnestensis Bartsch, 1999}

Figure $6 \mathrm{G}$ and $\mathrm{H}$

Halacarellus rottnestensis Bartsch, 1999c: 337-340, figures $2 \mathrm{~A}-\mathrm{I}, 3 \mathrm{~A}-\mathrm{H}$.

\section{New Material}

Australia: Western Australia: 1 female, Esperance, Duke of Orleans Bay, $33^{\circ} 55^{\prime} \mathrm{S}, 122^{\circ} 35^{\prime} \mathrm{E}$, from seagrass (Amphibolis sp.), 17 February 2003.

\section{Supplementary description}

Length of the single female found $735 \mu \mathrm{m}$. Dorsal plates with areolae with reticulate surface, delicately and minutely punctate surface and canaliculi which cross the integument. Areolae with canaliculi distinct (Figure 6H). OC with one delimited cornea and one very small and faint one. Gland pores on PD at 0.61. Ovipositor elongate, basal pair of papillae with slender, smooth genital spines, about $22 \mu \mathrm{m}$ in length. Apex of ovipositor with two pairs of slender, smooth genital spines, 25 $\mu \mathrm{m}$ in length, and two pairs of wide and flattened spines (Figure 6G), their outer edge dentate. Legs III and IV slender, length:height ratio of telofemora I to IV 2.7, 3.0, 3.3, 3.4; genua III and IV 3.1 times longer than high. Leg chaetotaxy, from trochanter to tarsus: $\operatorname{leg} 1,1,2,4,5,13$; leg II, 1, 2, 5, 5, 12; leg III, 2, 3, 3, 4, 5-6; leg IV, 0, 3, 3, 3, 6 .

\section{Remarks}

The two species $H$. lubricus and $H$. rottnestensis belong to the Halacarellus harioti group (Bartsch, 1999 c). Halacarellus rottnestensis is much larger than $H$. lubricus, the omamentation of its dorsal plates is weaker, the telofemora and genua of legs III and IV are much more slender and longer than in H. lubricus. A third Australian species of this group, H. katewilsonae, known from the Queensland Plateau, Queensland (Otto, 2001), is characterized by its slender $O C, P D$ and $G A$, more slender than in the other species.

The ovipositor is provided with differently shaped apical genital spines, some are long and slender, others wide and flattened. According to Womersley (1937), a similar difference in the shape 
of spines is present in the closely related $H$. harioti (Trouessart, 1889b). In other Halacarellus species, e.g. in H. discretus Bartsch, 1998, a Black Sea species (Bartsch, 1998), a difference in the shape of the antero- and posteroapical genital spines is present but less marked. Dissimilar apical genital spines are also present in Actacarus and Anomalohalacarus (Bartsch, 1976, 1999a), whereas in other genera, e.g. in Copidognathus, Isobactrus, Lohmannella, Halacarus, Metarhombognathus, Rhombognathus, Rhombognathides, and Scaptognathides species (Bartsch, 1975, 1977a, 1979b, 2000, 2003d, 2005a; Newell, 1984) the apical genital spines are rather similar in shape. The single basal pair of spines (or papillae) are in general different in shape.

\section{Distribution and ecology}

Western Australia, Rottnest Island and Esperance, from Amphibolis sp.

\section{Genus Halacaropsis Bartsch, 1996}

\section{Halacaropsis capuzina Bartsch, 1996}

Halacaropsis capuzina Bartsch, 1996b: 12-16, figures 63-87.

\section{New Material}

Australia: Western Australia: 1 deutonymph, WAM T 78331, Esperance, Duke of Orleans Bay, $33^{\circ} 55^{\prime} \mathrm{S}, 122^{\circ} 35^{\prime} \mathrm{E}$, from seagrass (Amphibolis sp.) with epiflora and fauna, 17 February 2003; 1 protonymph, SMF, Esperance, Duke of Orleans Bay, small algae with large amounts of debris, from rocks, 17 February 2003; 1 protonymph, ZMH, Esperance, Duke of Orleans Bay, demosponge with epiflora and fauna, 17 February 2003.

\section{Remarks}

The samples contained juveniles but no adults. The deutonymph idiosoma measures $548 \mu \mathrm{m}$, the protonymph $439-455 \mu \mathrm{m}$. The $\mathrm{AD}$ is longer than wide, anteriorly rounded and ending with a small frontal process. The setae ds- 2 , ds -3 and ds -4 are much longer and stronger than ds- 1 and ds -5 . The rostrum is about as long as the gnathosomal base. P-3 bears a seta. Telofemur to tibia I of the deutonymph bear $3,2,3$ spines, those of the protonymph 2,2,2 spines, tarsi I to IV of the deutonymph $3,2,1,1$ ventral setae, of the protonymph 1, 1, 0, 0 setae. The claw pectines with their numerous minute tines extend to the base of the claws. The median claw of the tarsi is bidentate.

At present, three Halacaropsis species are described from Australia, H. capuzina, known from Rottnest Island, Western Australia, H. warringi (Otto, 1993), from Guerilla Bay, New South Wales, and $H$. nereis Otto, 1999, from the Great Barrier Reef, Queensland (Bartsch, 1996b; Otto, 1993, 1999).
Another species is recorded from Geraldton, Western Australia (Lohmann, 1909; cf. Bartsch, 1996b). The Australian species are very similar in their general shape and distinguishing characters of the juveniles have not been described in detail. Halacaropsis nereis differs from others in that its tarsi II to IV end with smooth paired claws and a unidentate median claw, whereas $H$. capuzina, $H$. warringi and the juveniles from Duke of Orleans Bay have claw pectines and a bidentate median claw. Adults of $H$. capuzina and $H$. warringi can easily be separated by the shape of the anterior margin of the $A D$ and the ornamentation of the epicuticula, but unfortunately juveniles often differ from adults in these characters. The shape of the dorsal and ventral plates of the juveniles from Duke of Orleans Bay agrees with that of $H$. capuzina, the surface of the plates lacks the very marked filaments of $H$. warringi which are illustrated by Otto (1993: figures 5, 6), and P-3 bears a long, slender seta, similar to that of $H$. capuzina, whereas in $H$. warringi and $H$. nereis this seta is short, its tip blunt and denticulate. The juveniles from Esperance most likely belong to Halacaropsis capuzina.

\section{Distribution and ecology}

Western Australia, Rottnest Island and Esperance. Generally present, often abundant amongst the epifauna on Amphibolis, but present also amongst scrub-like corallines covering rocks and demosponges.

\section{Genus Halacarus Gosse, 1855}

\author{
Halacarus flavellus Bartsch, 1993 \\ Figure 7A-E
}

Halacarus flavellus Bartsch, 1993c: 53-56, figures $5 \mathrm{~A}-\mathrm{F}, 6 \mathrm{~A}-\mathrm{E}$

\section{New Material}

Australia: Western Australia: 1 female, WAM T 78332, 1 male, WAM T 78333, Esperance, Duke of Orleans Bay, $33^{\circ} 55^{\prime} \mathrm{S}, 1^{\circ} 32^{\circ} \mathrm{E}$, on seagrass (Amphibolis sp.) with epifauna and flora, 17 February 2003; 1 male, ZMH, Duke of Orleans Bay, $33^{\circ} 55^{\prime} \mathrm{S}, 122^{\circ} 35^{\prime} \mathrm{E}$, on seagrass Posidonia sp. from 40 $\mathrm{cm}$ depth, 10 February 2003; 1 female, SMF, Esperance, Lucky Bay, 33 $59^{\prime} \mathrm{S}, 122^{\circ} 13^{\prime} \mathrm{E}$, algae from rocks, $10-30 \mathrm{~cm}$ below water edge, 13 February 2003.

\section{Remarks}

Halacarus flavellus is a soft-skinned species. The females are 531-720 $\mu \mathrm{m}$ long, males 555-565 $\mu \mathrm{m}$ (the flattened frontal spine included - Figure 7A). The $\mathrm{AD}$ includes the ds-1 whereas the gland pores are within the striated integument (Figure 7A). The $O C$ are small, they include a cornea and the pore canaliculus. A PD is lacking. The female GA is 
swollen due to the cerotegument; one pair of the perigenital setae is within the striated integument, two pairs adjacent to the GO (Figure $7 B$ ). The males have a pair of outlying pgs either in the anterior margin of the genital plate, on small protuberances, or on sclerites immediately outside the plate. The $\mathrm{GO}$ is surrounded by about 90 perigenital setae. Both the setae on P-2 are inserted apically. A very delicate, maze-like or delicately reticulate cerotegument covers the leg segments. All the ventral setae on leg I are long, spiniform and apically tapering, their number from telofemur to tibia: $2,2,4$. The genu and tibia II bear one and two pairs of ventral setae, respectively (Figure $7 \mathrm{C}$ ); the ventromedial seta(e) of each pair is bipectinate, the ventral one long, smooth and tapering. The four ventral setae on tibiae III and IV are slender and smooth. The number of strong ventral setae of the tarsi I to IV is $2,1,1,1$, the number of dorsal setae 4 , $4,4,3$. The solenidion and famulus of tarsus I are similar in size (Figure 7D). The claws bear an apical cluster of tines (Figure $7 \mathrm{E}$ ).

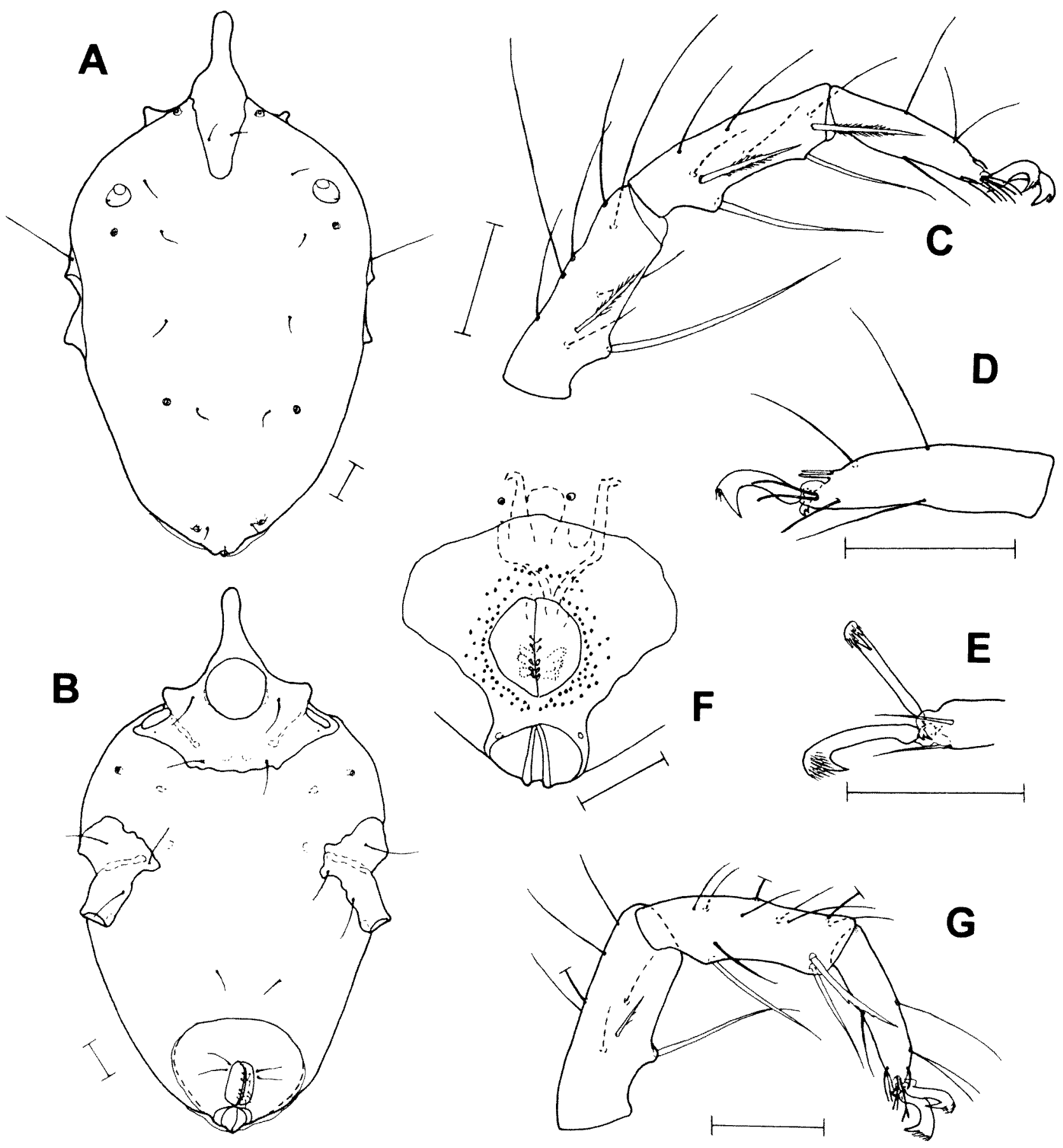

Figure 7 A-C. Halacarus flavellus Bartsch, 1993, female, A, idiosoma, dorsal; B, idiosoma, ventral; C, genu to tarsus II, medial; D, tarsus I, lateral (medial setae and claw omitted); E, tip of tarsus IV, ventral. F and G. Halacarus fuscatus Bartsch, 1993, male, F, genitoanal plate, ventral; genu to tarsus II, medial. Scale $=50 \mu \mathrm{m}$. 
Halacarus flavellus was described on the basis of females and males from Rottnest Island (Bartsch, 1993c). All those specimens had a long and slender frontal spine; in contrast, in the material from Esperance the frontal spine is flattened, spatulashaped. Else the specimens from the two localities agree in their diagnostic characters as well as in the substratum inhabited. They are expected to be conspecific.

\section{Distribution and Biology}

Western Australia, Rottnest Island and Esperance. Regularly taken in protected shallow water bays, amongst seagrass as well as algae.

\section{Halacarus fuscatus Bartsch, 1993}

Figure $7 F$ and $G$

Halacarus fuscatus Bartsch, 1993c: 56-58, figures 7A-G, 8A-D.

\section{New Material}

Australia: Western Australia: 1 female, WAM T 78334, Esperance, Duke of Orleans Bay, $33^{\circ} 55^{\prime} \mathrm{S}$, $122^{\circ} 35^{\prime} \mathrm{E}$, corallines on demosponge from just below water line, 17 February 2003; 1 male, ZMH, Duke of Orleans Bay, bay with seagrass (Amphibolis sp.) with epifauna and flora, 17 February 2003; 1 male, WAM T 78335, Esperance, Lucky Bay, 3359'S, $122^{\circ} 13^{\prime} \mathrm{E}$, tufts with small algae, 15 February 2003.

\section{Remarks}

The most marked character of this soft-skinned species is that the legs, gnathosoma and the cerotegument of the female GA are of a yellowbrown colour, but the rather thin dorsal and ventral plates lack such prominent colour. With the triangular frontal spine included, the female is 635 $\mu \mathrm{m}$ long, the males $470-560 \mu \mathrm{m}$. The first pair of gland pores are on the AD, followed by the ds-1. The OC are small, a PD absent. The idiosoma and especially the legs and gnathosoma are covered with delicately reticulate cerotegument. The cerotegument on the female GA is thick and uniform. One pair of the pgs is in the striated integument, two pairs on the female GA close to the GO. The GA of the male is wide, its outline strongly influenced by the orientation (and deformation/ distortion) of the specimen in the mounting medium. The spermatopositor is calyx-shaped (Figure 7F). Leg I has the typical number of 2, 2, 4 smooth, tapering bristles on telofemur, genu and tibia, respectively. The ventromedial seta on genu II is short, pectinate, the basal one of the two ventromedial setae on tibia II is slender, the apical one wide and pectinate (Figure $7 \mathrm{G}$ ). Tarsi I to IV bear 2, 1, 1, 1 strong ventral bristles. Tarsus III bears four dorsal setae. The paired claws end with a raised apical cluster of tines.
Both $H$. flavellus and $H$. fuscatus can be attributed to the Halacarus actenos group, named after $H$. actenos Trouessart, $1889 \mathrm{~b}$. Species of this group are characterized by the combination of: AD present, OC small or reduced, PD absent; pair of ds-1 slightly posterior to the level of gland pores; female GA uniformly covered with cerotegument, one pair of pgs within the striated integument anterior to GA, two pairs of pgs close to GO; spines on leg I tapering, almost equal in shape and size; ventromedial seta of genu II bipectinate; on tibia II distal one of ventromedial setae pectinate, basal seta pectinate or short and smooth; all tarsi with ventral seta(e). Halacarus fuscatus and $H$. flavellus differ in their colour (brown vs pale), the size of the frontal spine (short, tapering vs long, slender or spatulashaped), the position of glp-1 (on the AD vs in the striated integument), and the size and shape of the ventromedial setae on tibia II (basal seta slender, distal one strong and pectinate vs both setae strong and pectinate).

\section{Distribution and ecology}

Western Australia, Esperance and Rottnest Island. Extracted from an epiflora growing on seagrass, algal fronds and sponges.

\section{Halacarus helenae Bartsch, 1993}

Halacarus helenae Bartsch, 1993c: 59-61, figure 9A-J.

\section{New Material}

Australia: Western Australia: 1 female, WAM T 78336, Esperance, Lucky Bay, 33⒌'S, 122 $13^{\prime} \mathrm{E}$, sediment from $0.5 \mathrm{~m}$ depth, 15 February 2003; 1 female, SMF, same collection data; 1 female, $\mathrm{ZMH}$, same collection data.

\section{Remarks}

A small-sized species, measuring 340-410 $\mu \mathrm{m}$ from the short, wide frontal spine to the anal cone. The idiosoma is pale or somewhat light-brown, due to the translucent gut content, and there is no eye pigment present. The legs and idiosoma form a slightly curved unit. The AD and PD are coarsely reticulate, with ridges dividing each polygon, the striated integument is papillose; the surface of the ventral plates has a maze-like ornamented epicuticula and that of the legs is striated. The epicuticular layers on the female GA are slightly raised, somewhat bean-shaped, though not distinctly delimited from the anterior part of GA. None of the three pairs of perigenital setae is outlying, one pair is close to the anterior margin, one close to the posterior margin of $\mathrm{GO}$ and one pair between. The telofemora of the legs are flattened. Tarsus I bears two bristle-like ventral 
setae, tarsi II to IV 2, 1, 1 ventral setae, respectively. Tarsus III bears no more than three dorsal setae.

This Halacarus species is much smaller than the two above-mentioned species.

There were no males amongst the material studied.

\section{Distribution and ecology}

Western Australia, Rottnest Island and Esperance. Inhabitant of sediment from shallow water to $30 \mathrm{~m}$ depth. The collecting data, coarse sediment, as well as the shape, with the legs and idiosoma forming a slightly curved unit, and the absence of eyepigment are evidence that this species is psammobiont.

\section{Halacarus strigatus sp. nov. Figure $8 \mathrm{~A}-\mathrm{H}, 9 \mathrm{~A}-\mathrm{G}$}

\section{Material examined}

\section{Holotype}

male, WAM T 78337, Duke of Orleans Bay, $33^{\circ} 55^{\prime} \mathrm{S}, 122^{\circ} 35^{\prime} \mathrm{E}$, Esperance, Western Australia, Australia, about $1 \mathrm{~cm}$ thick tufts of small algae growing on sediment, just below low water line, 19 February 2003.

\section{Further material}

Australia: Western Australia: 1 protonymph, WAM T 78338, Esperance, Cape le Grand, New Island, $34^{\circ} 00^{\prime} \mathrm{S}, \quad 122^{\circ} 50^{\prime} \mathrm{E}$, Cystoseira sp. (Phaeophyta) from about $0.5 \mathrm{~m}$ depth, 6 February 2003.

\section{Etymology}

The name strigatus, from strigatus (Latin), striped, is derived from the striae in the epicuticula.

\section{Diagnosis}

Length of male $415 \mu \mathrm{m}$. Surface of plates, gnathosoma and legs with delicate striae in fingerprint-like or parallel arrangement. AD with short, triangular frontal spine. $A D, O C$ and $P D$ present. $O C$ with comea but no gland pore. PD with gland pore in margin of plate. Male GA with 31 pgs in an inner ring and 13 outlying setae. Pair of spines on telofemur I blunt. On tibia II basal one of ventromedial setae slender, apical one larger and bipectinate. Tarsi I to IV with 2, 0,0 , 0 ventral bristles and 4, 4, 4, 3 dorsal setae. Claws with accessory process and few delicate tines on arc of claw.

\section{Description}

Male. Length $415 \mu \mathrm{m}$, width $220 \mu \mathrm{m}$. Epicuticula of idiosoma, of plates and membraneous integument, densely striated, striae in fingerprint- like or parallel arrangement. Dorsal plates with scattered delicate canaliculi. Frontal process triangular (Figure 8A). Length of AD $140 \mu \mathrm{m}$, width $75 \mu \mathrm{m}$. Pair of glp-1 on AD, near lateral margin. Second and third pair of gland pores on platelets in striated integument, second pair in margin, third pair posterior to $\mathrm{OC} ; \mathrm{glp}-4$ in lateral margin of $\mathrm{PD}$. OC short, length $33 \mu \mathrm{m}$, width $26 \mu \mathrm{m}$; with single large cornea and, in posterior margin, a pore canaliculus. Length of PD $142 \mu \mathrm{m}$, width $75 \mu \mathrm{m}$; anterior rounded margin extending beyond pair of gland pores. Dorsal setae short; $\mathrm{ds}-1$ on AD posterior to glp-1, ds-2, ds-3 and $\mathrm{ds}-4$ in striated integument, ds-2 close to $\mathrm{OC}$, ds-3 medial to glp-3; pair of ds-5 in anterior margin of $\mathrm{PD}$ well anterior to pair of glp-4. Pair of $d s-6$ in posterior margin of PD immediately medial to glp-5.

Ventral plates with delicately striated integument. Length of AE $112 \mu \mathrm{m}$, width $202 \mu \mathrm{m}$. Apodemes between epimeral plates I and II very long, almost extending to third pair of ventral setae (Figure $8 \mathrm{~B}$ ). Length of PE $179 \mu \mathrm{m}$, extending to but not beyond insertion of leg IV; PE with one dorsal and three ventral setae; apodemes between epimeral plates III and IV short. Length of GA $169 \mu \mathrm{m}$, width $92 \mu \mathrm{m}$; anterior margin of plate ovate. Length of $\mathrm{GO} 38$ $\mu \mathrm{m}$, width $32 \mu \mathrm{m}$, distance between anterior margin of GO to that of GA equalling twice length of GO. Perigenital setae smooth; 31 pgs in an inner ring and 13 pgs in an outer ring (Figure 8C). Each genital sclerite with five sgs, of these four setae spiniform and one seta minute and setiform (Figure 8D). Three pairs of internal genital acetabula shining through integument.

Length of gnathosoma $115 \mu \mathrm{m}$, width $60 \mu \mathrm{m}$. Gnathosomal base rectangular in ventral aspect (Figure 8E); its epicuticula, as well as that of palps, delicately striated. Rostrum about as long as gnathosomal base and extending to end of P-2. Both pairs of maxillary setae on rostrum. Tectum slightly arched. P-2 with two dorsal setae at 0.5 and 0.9 , from basal to apical. P-3 with bluntly ending spine. P-4 with three setae in basal whorl, one lateral seta in middle of segment and two slender spurs at the tip.

Leg I wider than following legs. Genua of all legs about as long as telofemora and tibiae. Trochanters to tibiae with delicately striated epicuticula, striae in parallel or fingerprint-like arrangement (Figure $8 \mathrm{H}$ ); ornamentation partly absent on medial flank of basi- and telofemora III and IV. Tarsi I and II without such epicuticula. Tarsi III and IV with striated epicuticula in basal fifth, remainder almost smooth. Leg chaetotaxy: $\operatorname{leg} 1,1,2,8,11,13,8 ; \operatorname{leg}$ II, 1, 4, 7, 9, 11, 6; leg III, 2, 2, 6, 7, 9, 4; leg IV, 1, 2, 4, 5, 8, 3. Pair of spines on telofemur I bluntly ending, ventromedial spine much shorter than ventral spine (Figure 8F). Spines on genu (one pair) and tibia I (two pairs) tapering. Tarsus I ventrally with two 


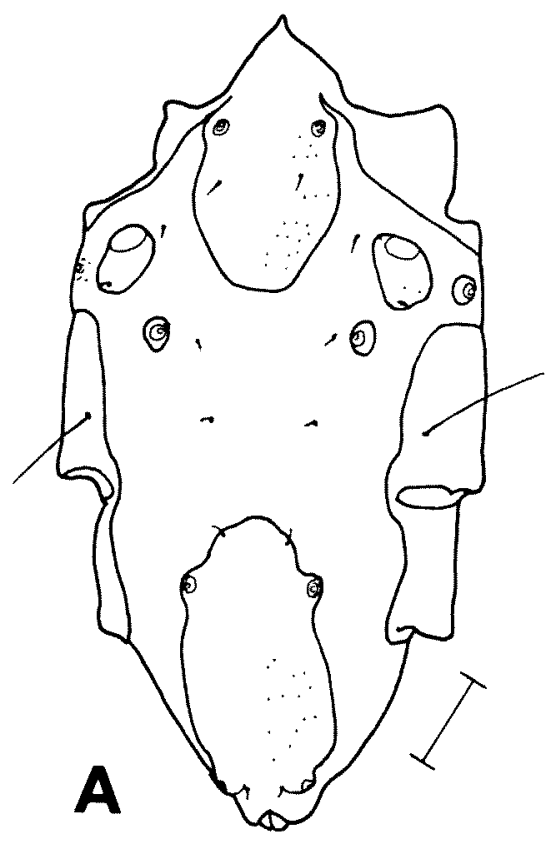

B

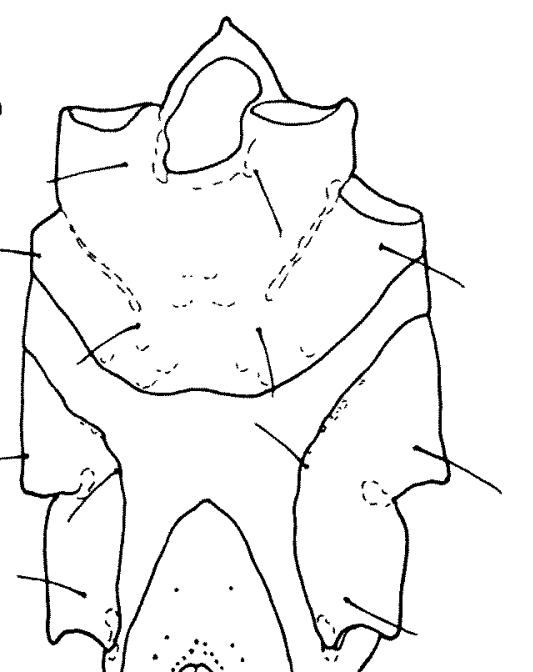

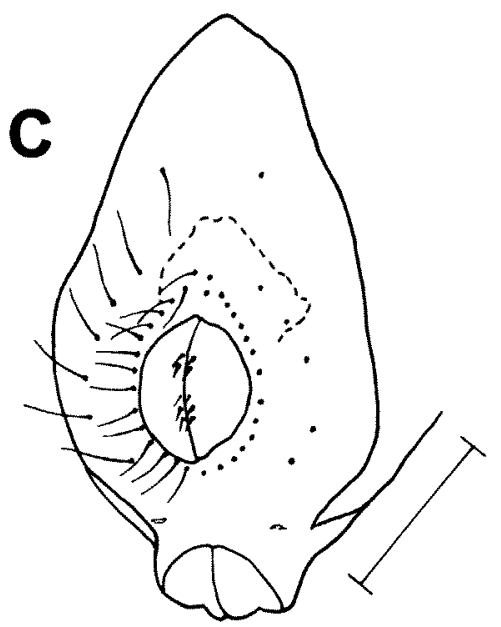
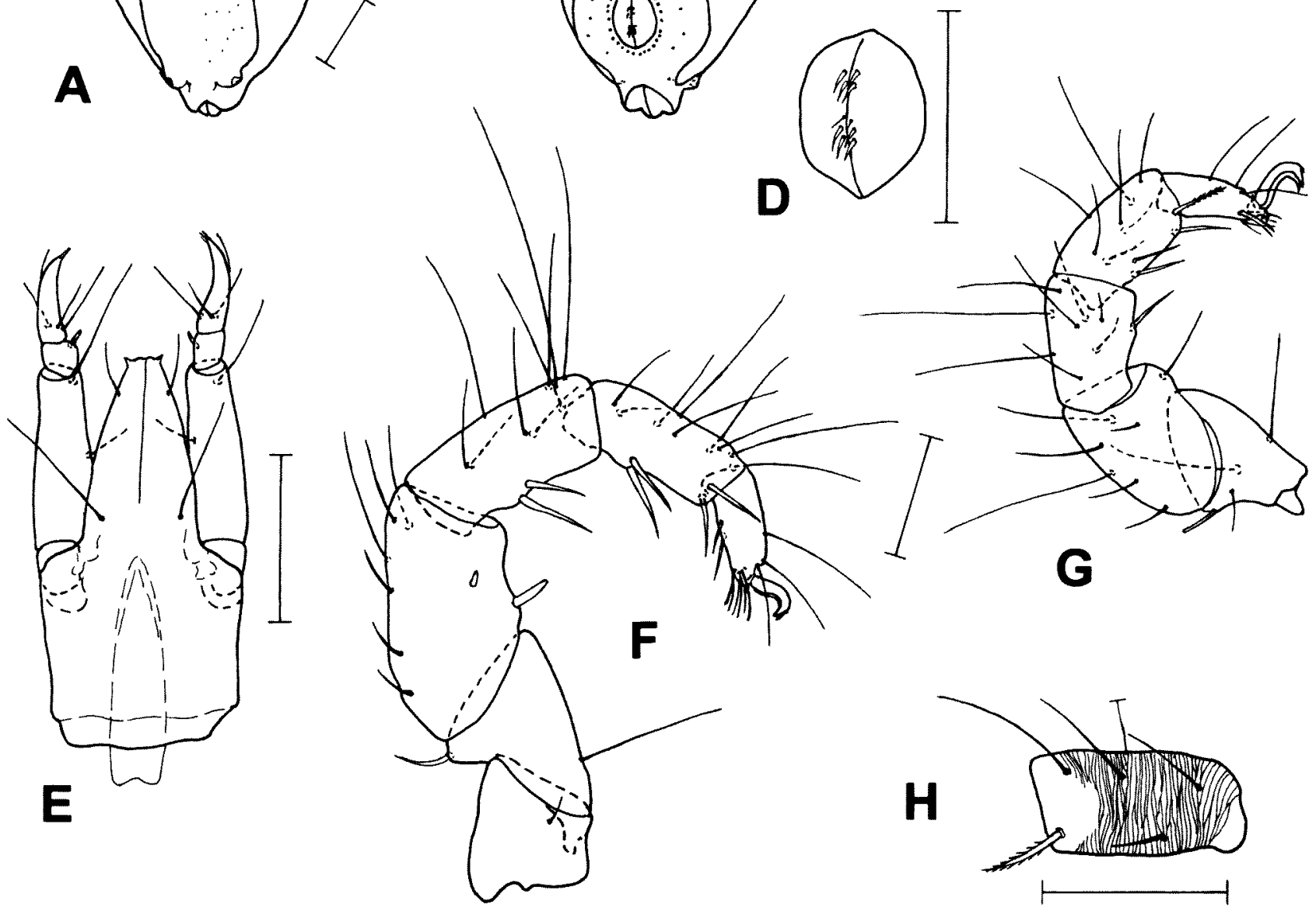

E

Figure 8 A-H. Halacarus strigatus sp. nov., male, A, idiosoma, dorsal; B, idiosoma, ventral; C, genitoanal plate, ventral; D, genital opening; E, gnathosoma, ventral; F, leg I, medial; $G$, basifemur to tarsus II, medial; $H$, tibia II, medial. Scale $=50 \mu \mathrm{m}$.

spiniform setae, apically with pair of eupathidia and pair of doubled pas; dorsally with three fossary setae; solenidion and famulus similar in size and 7 $\mu \mathrm{m}$ long (Figure 9C). Dorsal seta on basifemur II blunt (Figure $8 \mathrm{G}$ ). On tibia II two ventral setae tapering, basal one of ventromedial setae slender, distal one thicker and bipectinate (Figure $8 \mathrm{H}$ ). Solenidion on tarsus II in dorsomedial position, about $6 \mu \mathrm{m}$ in length (Figure 9D); tip of tarsus II with pair of eupathidia and pair of doubled pas.
Tibiae III and IV each with four slender, tapering ventral setae (Figure 9A and B). Tip of tarsus III with pair of slender pas; on tarsus IV both medial and lateral pas plumulose (Figure 9E).

Paired claws of legs I slightly smaller than those of following legs. Arc of claws with accessory process and few delicate tines; no tines on shaft of claws. Central sclerite with small claw-like process, with large ventral and delicate upper tooth.

Female. Not seen. Females and males of 


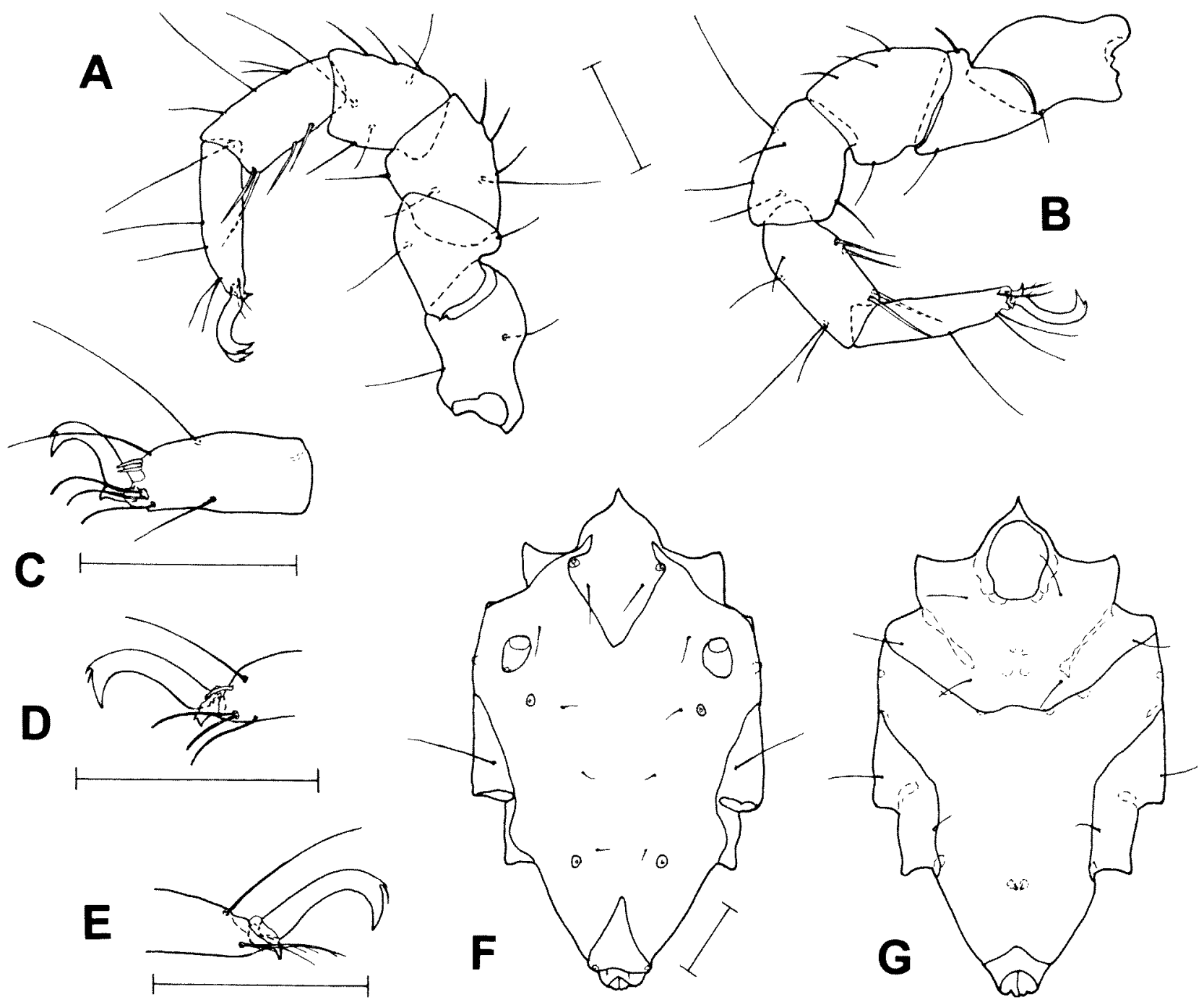

Figure 9 A-G. Halacarus strigatus sp. nov., A, leg III, medial, male; B, leg IV, medial, male; C, tarsus I, lateral, male (medial setae and claw omitted); D, tip of tarsus II, medial, male (lateral setae and claw omitted); E, tip of tarsus IV, lateral, male (medial setae and claw omitted); F, idiosoma, dorsal, protonymph; G, idiosoma, ventral, protonymph. Scale $=50 \mu \mathrm{m}$.

Halacarus species often differ in the size of PD, accordingly in females of this species the glp-4 may be on platelets contiguous or outside the PD, and the GA is expected to have bean-shaped areas lateral to the GO.

Protonymph. Length $325 \mu \mathrm{m}$, width $195 \mu \mathrm{m}$. Integument of dorsal and ventral plates, gnathosoma and legs with striated epicuticula. AD with a short frontal spine (Figure 9F). With five pairs of gland pores and six pairs of idiosomatic dorsal setae; pair of glp-1 on $\mathrm{AD}$, pair of $\mathrm{ds}-1$ posterior to gland pores. Setae ds- 1 and ds-2 longer than following setae. OC small, with delicate cornea. PD narrow, short, triangular. AE with three pairs of ventral setae, PE with one dorsal seta and two ventral setae (Figure 9G). Genital plate reduced, with pair of minute setae (subgenital setae); a pair of genital acetabula shining through striated integument. Telofemur to tibia I with 2, 2, 4 ventral spines; spines of telofemur I similar in size. Tibiae II to IV with 3, 2, 2 bristle-like ventral setae. None of ventral setae of tibia II coarsely plumose. Tarsi I to IV with 2, 0, 0, 0 ventral bristles and 4 (famulus excluded), 4, 4, 3 dorsal setae. Accessory process of claws not markedly raised.

\section{Remarks}

Halacarus strigatus has the character combination: $\mathrm{AD}, \mathrm{OC}$ and PD present; epicuticula of idiosoma, gnathosoma and legs with delicate striae in parallel or fingerprint-like arrangement; $O C$ with cornea but no gland pore; male GA with numerous outlying setae; tibia I with two pairs of tapering spines; tibia II with one smooth and one bipectinate ventromedial seta; tarsi III and IV with four and three dorsal but no ventral setae. Halacarus strigatus resembles species of the $H$. ctenopus group, but differs from the nine species mentioned 
(Bartsch, 2003b) in that the pair of glp-3 is not included in the OC. Halacarus aegyptus Viets, 1935 is another species with an overall similarity, but in that species the glp-3 are on the OC (in contrast to $H$. strigatus) and the glp-4 outside the PD. Other species with a character combination similar to that of $H$. strigatus are $H$. bisulcus Viets, 1927, $H$. elegans Newell, 1984, H. gracileunguiculatus Lohmann, 1907, and H. rismondoi Viets, 1940. Halacarus bisulcus and $H$. rismondoi are known from the North Atlantic, the Mediterranean included (Viets, 1940; Green and MacQuitty, 1987), $H$. elegans and $H$. gracileunguiculatus from the southern hemisphere, from the Auckland and Kerguelen Islands, respectively (Newell, 1984). The claws of tarsi II and III of $H$. bisulcus bear claw pectines, these are lacking in $H$. strigatus. The frontal spine of $H$. elegans is slender, much longer than in $H$. strigatus. The males of $H$. gracileunguiculatus and $H$. strigatus can be separated on the basis of the GA which differs in its length:width relation and arrangement of the pgs. In $H$. rismondoi both females and males have the fourth pair of gland pores outside the PD and the claws of tarsi II and III bear pectines.

Not included in this list of species are $H$. arnaudi Newell, 1984, H. laterculatus Viets, 1950, H. minor Lohmann, 1907, H. nanus Gimbel, 1919, and $H$. propinquus Viets, 1940 which are all from the southern hemisphere (Gimbel, 1919; Viets, 1950; Newell, 1984; Bartsch, 1993a). In dorsal aspect they demonstrate an overall similarity, but in contrast to $H$. strigatus males bear most of the pgs around the GO, there is just a single pair of outlying setae near the anterior margin of the GA. In the females of these five species the anterior GA is rounded or truncate, the anterior pair of pgs is within the striated integument anterior to the GO and there are no distinctly delimited bean-shaped cerotegumental areas on either side of the GO.

In the protonymph mentioned above the pairs of ds- 1 and ds- 2 are longer than the following setae and the two spiniform setae on telofemur are almost equal in size, in the male the dorsal setae demonstrate no marked difference in length but the spines on telofemur I differ in size. Nonetheless the male and protonymph are expected to be conspecific.

In most halacarid genera, protonymphs have a pair of genital acetabula but no perigenital or subgenital setae (Bartsch, 2003a). In contrast, in Halacarus species studied so far, protonymphs have a pair of minute setae close to the primordial genital slit. Similar setae are also present in Lohmannella species (Bartsch, 1977b).

\section{Distribution}

Western Australia, Esperance.
Genus Lohmannella Trouessart, 1901

\section{Lohmannella pinggi Otto, 1994}

Lohmannella pinggi Otto, 1994: 32-35, figures 1-8; Bartsch, 2005b: 296-298, figure 3A-G.

\section{New Material}

Australia: Western Australia: 1 female, WAM T 78339, Esperance, Nine Mile Beach, 33⒌'S, $121^{\circ} 47^{\prime} \mathrm{E}$, tufts of algae on wave-washed edge of limestone platform, 18 February 2003; 1 female, ZMH, same collection data.

\section{Remarks}

Length of the idiosoma 278-300 $\mu \mathrm{m}$. The characters of the specimens agree with those presented in Bartsch (2005b: figure A-D), the length of the $O C$ is at least twice the width, there is one distinct and one small, indistinctly demarcated cornea. The $\mathrm{ds}-4$ are situated in the striated integument posterior to the $\mathrm{OC}$ and the small ds-5 on the PD immediately posterior to the pair of gland pores. The portion of the PE anterior to the insertion of leg III is long and extends to or beyond the level of the ventromarginal pair of gland pores.

\section{Distribution and ecology}

Western Australia (Rottnest Island and Esperance), Victoria and New South Wales. The specimens from Esperance are from the wavewashed tidal edge of a rocky platform.

\section{Lohmannella septemsetosa Bartsch, 2005 Figure 10A-C}

Lohmannella septemsetosa Bartsch, 2005b: 293-296, figures $1 \mathrm{~A}-\mathrm{K}, 2 \mathrm{~A}-\mathrm{F}$.

\section{New Material}

Australia: Western Australia: 1 female, WAM T 78340, Esperance, Duke of Orleans Bay, 335's, $122^{\circ} 35^{\prime} \mathrm{E}$, tufts of algae and sediment rich in debris, $50 \mathrm{~cm}$ depth, 19 February 2003; 1 larva, author's collection, same collection data.

\section{Supplementary description}

Female. Idiosomal length $447 \mu \mathrm{m}$, gnathosomal length $317 \mu \mathrm{m}$, ratio idiosoma:gnathosoma 1:0.71. Surface of dorsal and ventral plates, gnathosoma and legs with irregularly reticulate epicuticula. Gland pores large. Pair of ds-1 posterior to level of gland pores. OC with gland pore in middle of plate. Anterior margin of GA truncate, length $224 \mu \mathrm{m}$, width $170 \mu \mathrm{m}$, with 8-9 pairs of pgs (Figure 10A). Genital sclerites with four pairs of setae. P-2 without spiniform ventral process. Genu and tibia I with four and six to seven bipectinate ventral setae. Tibiae II to IV with $6,5,5$ ventral setae; number of ventromedial/ventrolateral bipectinate setae: $3 / 1,2$ / 

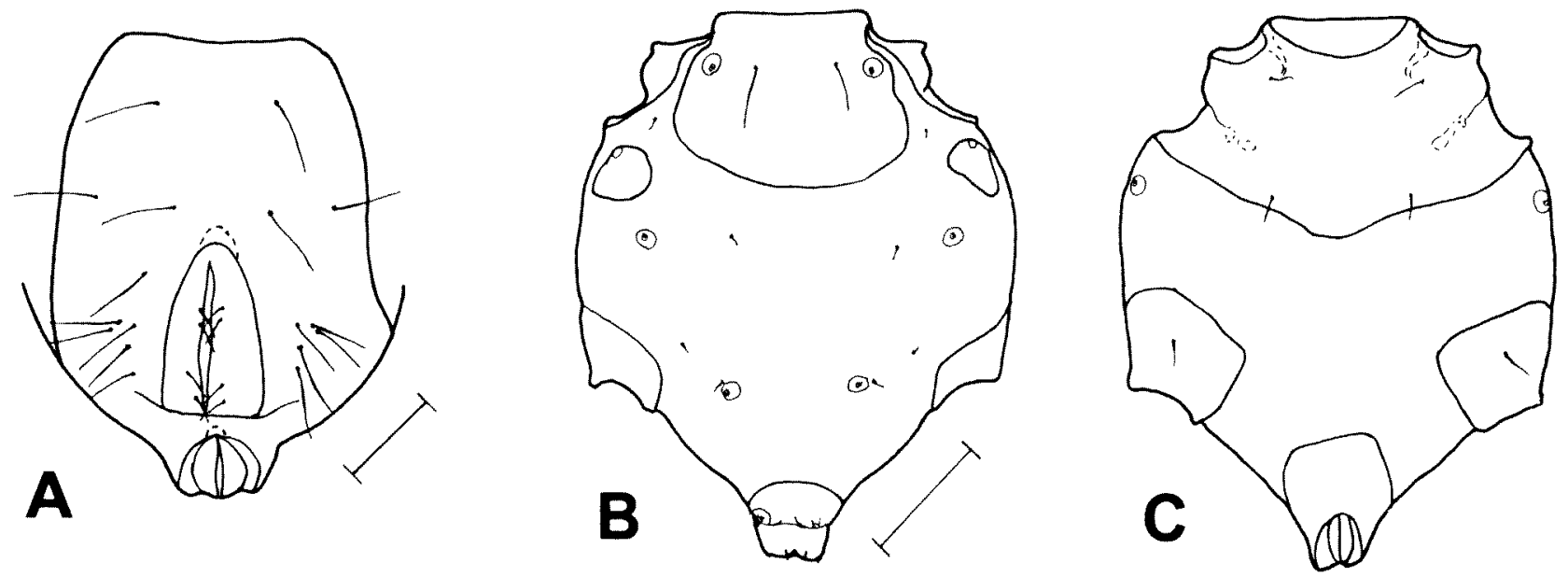

Figure 10 A-C. Lohmannella septemsetosa Bartsch, 2005, A, genitoanal plate, female; B, idiosoma, dorsal, larva; C, idiosoma, ventral, larva. Scale $=50 \mathrm{um}$.

3,0/3; other setae slender, not distinctly bipectinate. Number of bipectinate ventral setae on tarsi I to IV: $2,2,3,2$, number of eupathidia or slender ventral setae: $6,3,1,1$; in addition, all tarsi with pas. Claws with accessory process.

Larva. Length of idiosoma $202 \mu \mathrm{m}$, width $167 \mu \mathrm{m}$; length of gnathosoma $119 \mu \mathrm{m}$. OC much smaller than in adults, not including the pair of gland pores (Figure 10B). PD very short, with fifth pair of gland pores. AE with pair of internal tubes and two pairs of setae; PE with a single ventral seta (Figure 10C). Tibiae I, II and III each with one pair of ventral setae. Tarsi I to III with 2, 1, 0 bipectinate ventral setae.

\section{Remarks}

Lohmannella septemsetosa bears large gland pores, as most southern hemisphere Lohmannella species. Other Lohmannella from Australia are $L$. arenaria Bartsch, 1993, L. dictyota Bartsch, 1992a, and L. pinggi (Bartsch, 1993d; Otto, 1994, 2000b). The dorsal plates of $L$. arenaria are much wider than in $L$. septemsetosa and the second palpal segment bears two cuticular ventral processes which are lacking on the palps of $L$. septemsetosa. Lohmannella dictyota is characterized by its elongate PD, 1.7 times longer than wide, and the fused P-1. Lohmannella pinggi has unusual elongate $\mathrm{OC}$, their length is twice or more the width. Amongst the presently known Lohmannella species, L. kerguelensis Lohmann, 1907 is most similar to $L$. septemsetosa. Lohmannella kerguelensis is known from Kerguelen and the Palmer Peninsula (Bartsch, 1993a), the most marked difference is that in $L$. kerguelensis the ds-3 are included in an anteriorly arched PD.

\section{Distribution and ecology}

Western Australia, Esperance. The present records are from shallow water, from algal tufts with debris.

\section{Genus Rhombognathus Trouessart, 1888}

Rhombognathus delicatulus Bartsch, 2000

Rhombognathus delicatulus Bartsch, 2000: 171-174, figures 4A-H, 5A-I, 6A-D; Bartsch, 2003c: 260 , 261, figures 2A-G; Bartsch, 2005e: 376-377. figure $1 \mathrm{~A}-\mathrm{D}$.

\section{Remarks}

Rhombognathus delicatulus is small and slender, its length about $187-202 \mu \mathrm{m}$. The anal cone is conspicuously narrow, the anal sclerites squeezed between the anal valves. Each claw has a very narrow accessory process with one or two tines. The $\mathrm{PD}$ is faintly reticulated and bears a single pair of setae. Telofemur I is slender, about 1.8 times longer than high, and telofemora I to IV bear $4 / 1,3-4 / 1$, $3 / 0,3 / 0$ dorsal/ventral setae.

\section{Distribution and ecology}

Queensland, Great Barrier Reef, and Western Australia, Dampier and Esperance. Inhabitant of algae, coral rubble and coarse sand, from low water edge to depth of $38 \mathrm{~m}$.

\section{Rhombognathus lepidus Bartsch, 1993}

Rhombognathus lepidus Bartsch, 1993b: 29-31, figure 7A-H; Bartsch, 2005e: 378-380, figure 2A-H.

\section{Remarks}

This species is small and slender, its length $187-$ $239 \mu \mathrm{m}$. The PD is uniformly though faintly reticulate, as in the above mentioned $R$. delicatulus, but the anal sclerites are distinct and extend beyond the anal valves and the accessory process of the claws is slightly widened, bearing 9-10 tines. The telofemur $I$ is slender, about 2.1 times longer than high and the number of dorsal/ 
ventral setae on the telofemora I to IV is $4 / 2,4 / 2,3$ / $1,3 / 1$

\section{Distribution and ecology}

Western Australia, from Dampier and Esperance. Records are from just beneath the low water edge to about $8 \mathrm{~m}$, from algal turf from rocky platforms and the surface of demosponges.

\section{Rhombognathus marginalis Bartsch, 1993}

Rhombognathus marginalis Bartsch, 1993b: 31-33, figure 8A-G; Bartsch, 2005e: 380-383, figure 3AF, 4A-F.

\section{Remarks}

The length of females is $240-244 \mu \mathrm{m}$, of males $215-225 \mu \mathrm{m}$. This is one of the species with rakelike claws, each bearing 22-24 tines. Adults have small ventral plates which are restricted to the margins; the major parts of the venter is covered by striated integument. Both the adults and juveniles can be distinguished from others on the basis of the very short leg segments (telofemur I 1.4-1.5 times longer than high), and absence of a second ventral seta on tibiae III and IV (four setae on each tibia).

\section{Distribution and ecology}

Western Australia, Rottnest Island and Esperance. An inhabitant of lower tidal algae exposed to swell.

\section{Rhombognathus tener Bartsch, 2005}

Rhombognathus tener Bartsch, 2005e: 384-387, figure $5 \mathrm{~A}-\mathrm{H}, 6 \mathrm{~A}-\mathrm{E}$.

\section{Remarks}

The females are 307-310 $\mu \mathrm{m}$ long, males 253-290 $\mu \mathrm{m}$. The claws are rake-like, as in the above mentioned $R$. marginalis, the accessory process bears 16-19 tines. The PD is faintly foveate, without marked costae, and bears two pairs of setae. The plates AE, PE and GP are fused to a ventral shield in both the females and males. Telofemur I is about 1.7 times longer than high and there are $3-4 / 1,3-4$ / $1,2-3 / 0,2-3 / 0$ dorsal/ventral setae on the telofemora I to IV.

\section{Distribution and ecology}

At present known only from Esperance Bay, Western Australia, from subtidal brown algae (Scaberia sp.).

\section{Rhombognathus vulgaris Bartsch, 2005}

Rhombognathus vulgaris Bartsch, 2005e: 388-391, figure $7 \mathrm{~A}-\mathrm{I}, 8 \mathrm{~A}-\mathrm{C}$.

\section{Remarks}

The females are 252-279 $\mu \mathrm{m}$ long, the males $225-269 \mu \mathrm{m}$. Rhombognathus vulgaris is most similar to $R$. tener; the rake-like claws bear 21-22 tines. As in $R$. tener, there are two pairs of setae on the PD, but the PD of $R$. vulgaris is more narrow and bears a pair of costae. The ventral plates AE, PE and GP are fused in both the female and male. Telofemur $I$ is 1.8 times longer than high, its shape accordingly similar to that of $R$. tener, but the telofemora I to IV bear $4 / 2,4 / 2,3 / 1-$ $0,3 / 1-0$ dorsal/ventral setae.

\section{Distribution and ecology}

Esperance, Western Australia. A very common species amongst macro-algae on granite rocks and limestone platforms exposed to strong and moderate swell. Records are from the low water edge to about $2 \mathrm{~m}$ water depth.

\section{Genus Scaptognathus Trouessart, 1889}

\section{Scaptognathus arenarius sp. nov.} Figure 11A-G, 12A-G

\section{Material}

\section{Holotype}

male, WAM T 78341, Duke of Orleans Bay, 335' $\mathrm{S}, 122^{\circ} 35^{\prime} \mathrm{E}$, Esperance, Western Australia, Australia, patch with unsorted sediment, just below low water line, 10 February 2003.

\section{Paratypes}

Australia: Western Australia: 1 female, WAM T 78342, same collection data; 1 larva, WAM T 78343, same collection data; 1 female, SMF, same collection data; 1 female and 1 male, $\mathrm{ZMH}$, same collection data.

\section{Etymology}

The name is derived from arena (Latin), sand, arenarius, living in sand, as the only records are from a patch of sand.

\section{Diagnosis}

Dorsal plates minutely foveate. Length of female 246-278 $\mu \mathrm{m}$, of male 240-266 $\mu \mathrm{m}$. Gnathosoma 0.7 of length of idiosoma. Posterior margin of $\mathrm{AD}$ wide. OC large, gland pore at 0.8 , dorsum with seven pairs of dorsal setae. Female and male GA bipartite. Female with three pairs of pgs and two pairs of sgs, male with six to seven pairs of pgs close to GO, two pairs of outlying setae and two pairs of sgs. Tibia I with five bipectinate setae. Genu to tarsus I with 2 , 5,1 bipectinate setae; tibiae II to IV with $2(-4),(2-) 3$, 3 bipectinate setae, tarsi II to IV with $1,0,0$ bipectinate ventral setae. Claws with minute 
accessory process. Central sclerite with minute claw-like process.

\section{Description}

Male. Length 240-266 $\mu \mathrm{m}$, length of holotype 260 $\mu \mathrm{m}$, width $165 \mu \mathrm{m}$. Dorsal plates completely ornamented with numerous small, rounded to ovate foveae, 0.5 to $2 \mu \mathrm{m}$ in diameter or length. Each fovea with delicate canaliculi (oil immersion) (Figure 11D). First pair of gland pores almost at the level of insertion of leg $\mathrm{I}$. Anterior margin of $\mathrm{AD}$ truncate, posterior margin very broadly rounded (Figure 11A), length of plate $102 \mu \mathrm{m}$, width $112 \mu \mathrm{m}$. Length of $\mathrm{OC} 30 \mu \mathrm{m}$, width $25 \mu \mathrm{m}$. Gland pore near posterior margin, at 0.8 . Anterior margin of PD truncate, with evenly rounded corners, length of PD $122 \mu \mathrm{m}$, width $104 \mu \mathrm{m}$. Pair of gland pores in posterior margin of plate. First pair of dorsal setae much longer than following setae, situated close to pair of gland pores. Pairs $d s-2$ to $d s-5$ within striated integument, ds-2 very close to anterior margin of $\mathrm{OC}, \mathrm{ds}-3$ near margin of $\mathrm{PE}, \mathrm{ds}-4$ posterior to $\mathrm{AD}$ and ds -5 lateral to anterior margin of PD; setae ds-6 and ds-7 on PD, ds-6 level with insertion of leg $I V$, at 0.3 , ds-7 at 0.7 .

Ventral plates irregularly foveate (Figure 11B), with delicate canaliculi when focused on procuticula; on PE integument along medial margin almost smooth. Length of AE $85 \mu \mathrm{m}$, width $157 \mu \mathrm{m}$, plate with pair of epimeral pores and three pairs of short setae. Length of PE $117 \mu \mathrm{m}$, extending far beyond insertion of leg IV; PE with one small lateral seta and three ventral setae. GA bipartite, total length $125 \mu \mathrm{m}$, posterior part 107
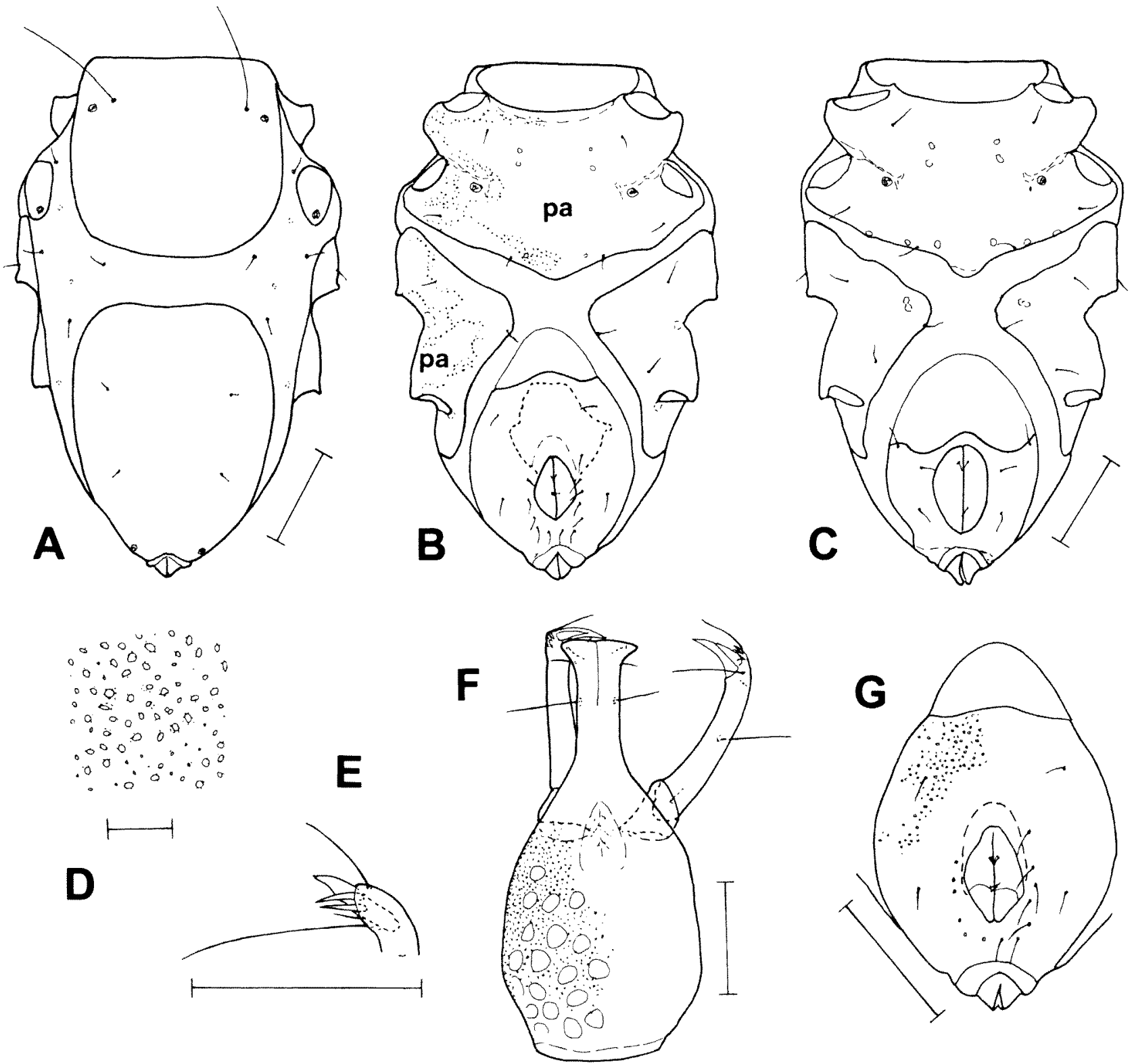

Figure 11 A-G, Scaptognathus arenarius sp. nov., A, idiosoma, dorsal, male; B, idiosoma, ventral, male; C, idiosoma, ventral, female; $D$, middle part of $A D$, male; $E$, tip of palp, female; $F$, gnathosoma, ventral, male; $G$, genitoanal plate, male $(\mathrm{pa}=$ foveate areola $)$ Scale $=50 \mu \mathrm{m}$. 
$\mu \mathrm{m}$, width $87 \mu \mathrm{m}$. Surface of posterior part with small foveae. Length of GO $33 \mu \mathrm{m}$, width $20 \mu \mathrm{m}$. Interval between anterior margin of $\mathrm{GO}$ and that of posterior GA equalling 1.3 times length of $\mathrm{GO}$. With six to seven short pgs lateral and posterior to GO and two pairs of outlying setae (Figure 11G). Anterior pair of outlying setae level with insertion of leg IV, posterior pair lateral to GO. Genital sclerites with two pairs of sgs. Length of spermatopositor $60 \mu \mathrm{m}$, width $47 \mu \mathrm{m}$, extending to margin of posterior GA.

Length of gnathosoma $187 \mu \mathrm{m}$ or 0.72 of idiosomal length, width $88 \mu \mathrm{m}$. Dorsal flank of gnathosomal base almost uniformly covered with small, irregularly shaped foveae, ventral flank with large, ovate 'cells', 15-17 $\mu \mathrm{m}$ in diameter, each surrounded by minute foveae (Figure 11F). Pharyngeal field small. Rostrum spatula-shaped, apically truncate. Both pairs of maxillary setae situated in anterior portion of rostrum, truncate apex with two pairs of rostral setae. Palps attached dorsally, P-1 almost contiguous. Palps twosegmented, parts equalling $\mathrm{P}-2$ to $\mathrm{P}-4$ fused. Two setae in part of palp representing $\mathrm{P}-2$, large spine in that of P-3, and basal spine, two long setae, minute apical seta and two apical spiniform setae in that of P-4 (Figure 11E).

Legs slender; leg I longer than the other legs. Ventrolateral flanks of telofemora and lateral flank of trochanters III and IV with foveate integument. Telofemora slender, their length:height ratio 3.2, 2.5, 2.4 and $2.4: 1$, from leg I to IV, respectively. Leg chaetotaxy: leg I, 1, 1, 6, 7, 8, 5; leg II, 1, 1, 5, 4, 5, 5; leg III, 1, 1, 2, 2, 5-6, 3; leg IV, 1, 1, 2-3, 3, 6, 3 . Ventromedial seta of telofemur I bristle-like and bipectinate, ventral seta almost smooth (Figure 12A). Telofemur II with $4 / 1 \mathrm{dorsal} /$ ventral setae (Figure 12B). Telofemora III and IV with $2 / 0$ and $2 /$ 0-1 dorsal/ventral setae, respectively (Figure $12 \mathrm{C}$ and D), in paratype male with $2 / 1$ and $2 / 0$ setae, respectively. Genu to tarsus I with $2,5,1$ bipectinate setae; tibiae II to IV with 2, 2-3, 3 such setae, and tarsi I to IV with 1, 1, 0, 0 bipectinate ventral setae. Paratype male with two bipectinate setae on one of tibiae II and three such setae on the other. In holotype, tibia III on one side with two bipectinate setae (ventralmost seta lacking), the other tibia III, as in paratype male, with three bipectinate setae. Tarsus I with tubiform solenidion, $14 \mu \mathrm{m}$ in length, and digitiform, solid famulus (Figure 12E), tip of tarsus with pair of doubled pas. Tarsus II with tubiform dorsomedial solenidion, $10 \mu \mathrm{m}$ long, situated between two distal fossary setae (Figure 12F). Tip of tarsus II, III and IV each with pair of pas singlets.

Claws with accessory process but no pecten. Central sclerite with rather inconspicuous, claw-like process.

Female. Length 246-278 $\mu \mathrm{m}$, length of gnathosoma 190-200 $\mu \mathrm{m}$. Dorsal aspect as in male. Genital plate bipartite. Posterior GA with three pairs of pgs, one pair in anterolateral angles of posterior GA, the others close to GO. Genital sclerites with anterior pair of sgs; posterior sgs paired, single-sided (Figure 11C) or absent. Telofemora III and IV with $2 / 1$ and 2/0 dorsal/ ventral setae, respectively. One of females with anomalous combination of three and four bipectinate ventral setae on tibia II, the other two females with two bipectinate setae on tibia II.

Larva. Length of idiosoma $113 \mu \mathrm{m}$, of gnathosoma $100 \mu \mathrm{m}$. Dorsal plates very delicately foveate, at low magnification apparently smooth. PD much shorter than in adults (Figure 12G); gland pores obscured. AE with two pairs of setae; middle portion distinctly foveate. PE with single ventral seta. Genu, tibia and tarsus I with 2, 2, 1 bipectinate bristles, respectively. Bipectinate bristles on genu, tibia and tarsus II numbering 1, 2, 1; on tibia II ventromedial bristle long, ventrolateral one short. Tibia III with pair of bipectinate bristles.

\section{Remarks}

Scaptognathus arenarius is characterized by the combination of: $O C$ large and gland pore at about 0.8 , GA bipartite in both female and male and tibia I with five bipectinate setae. The majority of species have short $O C$, rounded or wider than long and the gland pore is in about the middle of the plate. Elongate OC are present in $S$. gibbosus Bartsch, 1977, S. pacificus Newell 1971, S. newelli Bartsch, 1988 , and $S$. trouessarti Halbert, 1915. The tibiae I of S. gibbosus, S. newelli and $S$. pacificus have three bipectinate setae. The three species are known from the Pacific (Bartsch 1977c; Newell, 1971, 1984), in addition, there is a record of $S$. gibbosus from the Indian Ocean (Morselli \& Mari, 1986). S. trouessarti is a species from the north-eastern Atlantic (Halbert, 1915); according to the re-description by Abé and O'Connor (1991) there is no large gland pore on the OC.

\section{Distribution and ecology}

Western Australia, Esperance. Inhabiting medium-sorted sediment.

\section{Genus Simognathus Trouessart, 1889}

\section{Simognathus cruciferus Bartsch, 2005}

Simognathus cruciferus Bartsch, 2005b: 298-300, figure $4 \mathrm{~A}-\mathrm{L}$.

\section{Remarks}

Length $375 \mu \mathrm{m}$. The dorsal plates are pale, their surface almost uniformly foveate, the integument crossed by numerous delicate canaliculi. The AD and $\mathrm{OC}$ bear cornea-like structures. The $\mathrm{OC}$ are 


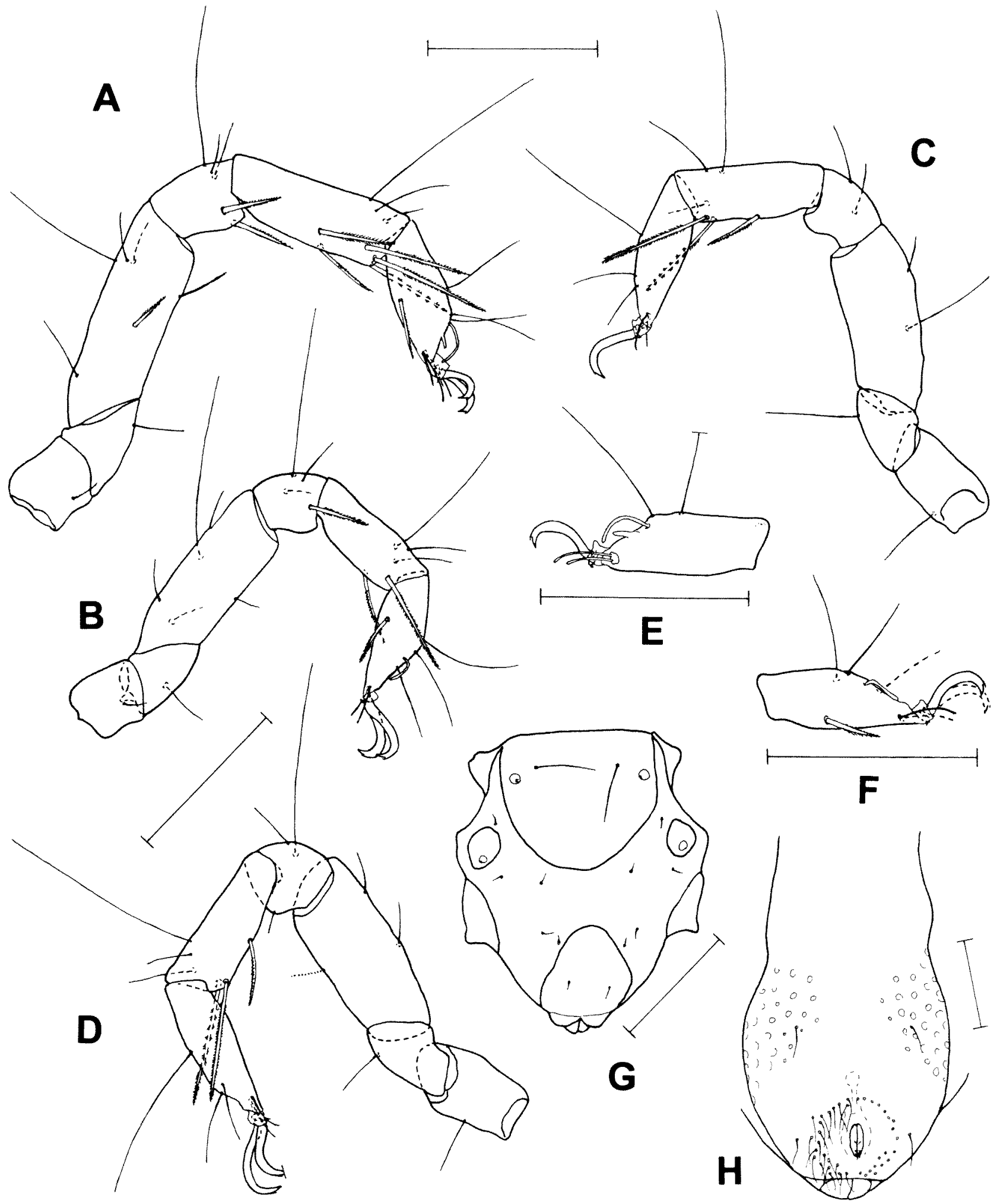

Figure 12 A-G. Scaptognathus arenarius sp. nov., A, leg I, medial, male; B, leg II, medial, male; C, leg III, medial, male; D, leg IV, medial, male (dotted seta present only on opposite leg); E, tarsus I, lateral, male (medial setae and claw omitted); F, tarsus II, medial (lateral fossary seta and claw in broken line), male; $G$, idiosoma, dorsal, larva. H. Simognathus uniscutatus Bartsch, 1994, area of genitoanal plate, male. Scale $=50 \mu \mathrm{m}$.

almost triangular. The pair of $\mathrm{d} s-4$ inserts on the PD. The adanal setae are in a ventral position. The integument of the marginal areolae of the $\mathrm{AE}$ is foveate and crossed by canaliculi whereas it is almost smooth in a cross-shaped median area. On the GA similar smooth integument is shaped like a $T$. The anterior margin of the female GA is arched. On the $\mathrm{P}-2$ there is a ventral protuberance and a bristle. Tibia I bears a wide but short, bluntly ending spine. 
Table 1 Non-Copidognathinae (Acari: Halacaridae) from Western Australia, from Esperance, Dampier and Rottnest Island, and further records of these species from in and outside Australia. (-, no record; E, Esperance; D, Dampier; NSW, New South Wales; RI, Rottnest Island; QLD, Queensland; VIC, Victoria; WA, Western Australia).

\begin{tabular}{lccc}
\hline WA localities & $\begin{array}{c}\text { other Australian } \\
\text { localities }\end{array}$ & $\begin{array}{c}\text { localities outside } \\
\text { Australia }\end{array}$ \\
\hline
\end{tabular}

Actacarus australis Bartsch, 1993

Actacarus festivus Bartsch, 2003

Actacarus pacificus Bartsch, 1979

Actacarus sp.

Agaue brevipes Bartsch, 1999

Agaue circellaris Bartsch, 1999

Agaue scita Bartsch, 1999

Agaue similis sp. nov.

Agaue subglabra Bartsch, 1999

Agaue tenuipes Bartsch, 1999

Agauopsis aequilivestita Bartsch, 1996

Agauopsis arborea Bartsch, 2003

Agauopsis australiensis Bartsch, 1996

Agauopsis calidictyota sp. nov.

Agauopsis dasyderma Bartsch, 2003

Agauopsis elaborata Bartsch, 1996

Agauopsis fenneri Otto, 1999

Agauopsis cf. fenneri Otto, 1999

Agauopsis miliaris Bartsch, 2005

Agauopsis mokari Otto, 1994

Agauopsis moorea Bartsch, 1992

Agauopsis obtusa Bartsch, 2003

Agauopsis ornatella Bartsch, 1996

Agauopsis sp.

Anomalohalacarus dampierensis Bartsch, 2003

Anomalohalacarus macellus Bartsch, 1993

Arhodeoporus disparilis Bartsch, 1997

Arhodeoporus corallicolus Otto, 2000

Arhodeoporus leptopus Bartsch, 1997

Arhodeoporus psammophilus Bartsch, 1993

Arhodeoporus robustus sp. nov.

Arhodeoporus wadjemupis Bartsch, 1997

Atelopsalis pacifica Bartsch, 1985

Australacarus pustulatus Bartsch, 1993

Bradyagaue exilis Bartsch, 2004

Bradyagaue scutella Bartsch, 1992

Halacarellus lubricus Bartsch, 1986

Halacarellus rottnestensis Bartsch, 1999

Halacaropsis capuzina Bartsch, 1996

Halacarus arenarius Bartsch, 1994

Halacarus celatus Bartsch, 1994

Halacarus discophorus Bartsch, 1994

Halacarus flavellus Bartsch, 1993

Halacarus fuscatus Bartsch, 1993

Halacarus helenae Bartsch, 1993

Halacarus mitrellus Bartsch, 1994

Halacarus parvulus Bartsch, 1994

Halacarus psammophilus Bartsch, 1994

Halacarus strigatus sp. nov.

Halacarus spp.

RI
$D$
D, E, RI
RI
E, RI
RI
RI
E
E, RI
E, RI

RI

$\mathrm{D}$

RI

E

$\mathrm{D}$

RI

$\overline{\mathrm{D}}$

E

D

$\mathrm{D}$

RI

RI

D

RI

RI

D

E, RI

E

RI

E, RI

RI

E

RI

E

E, RI

E, RI

RI

RI

RI

E, RI

E, RI

E, RI

RI

RI

RI

E

RI
$-$

Japan, Hawaii, Chile

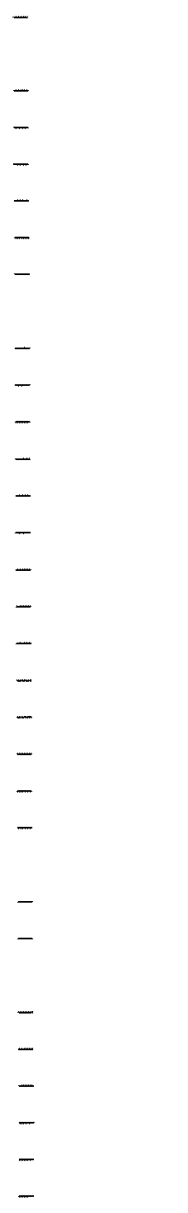

India (East), Philippines

NSW

New Zealand

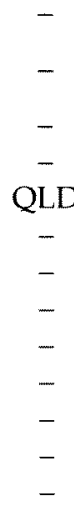


Table 1 (cont.)

WA localities other Australian localities outside localities Australia

Isobactrus australiensis Bartsch, 2002

Isobactrus obesus Bartsch, 1992

D

$\mathrm{D}$

\section{RI}

Lohmannella pinggi Otto, 1994

Lohmannella septemsetosa Bartsch, 2005

Rhombognathus biscutatus Bartsch, 1993

Rhombognathus delicatulus Bartsch, 2000

Rhombognathus dispar Bartsch, 2003

Rhombognathus foreolatus Bartsch, 1993

Rhombognathus latens Bartsch, 1993

Rhombognathus latibulus Bartsch, 1993

Rhombognathus lathridius Bartsch, 2000

Rhombognathus lepidus Bartsch, 1993

Rhombognathus levigatus Bartsch, 2000

Rhombognathus marginalis Bartsch, 1993

Rhombognathus ocularis Bartsch, 2002

Rhombognathus petraeus Bartsch, 2003

Rhombognathus placidus Bartsch, 1993

Rhombognathus psammophilus Bartsch, 1993

Rhombognathus scutulatus Bartsch, 1983

Rhombognathus tener Bartsch, 2005

Rhombognathus thalassinus Bartsch, 1993

Rhombognathus vulgaris Bartsch, 2005

Scaptognathides australis Bartsch, 1993

Scaptognathides hawaiiensis Bartsch, 1988

Scaptognathides ornatus Bartsch, 1988

Scaptognathus arenarius sp. nov.

Scaptognathus australis Bartsch, 1993

Scaptognathus exquisitus Otto, 2000

Scaptognathus peregrinus Bartsch, 1993

Scaptognathus sp.

Simognathus cruciferus Bartsch, 2005

Simognathus delicatulus Bartsch, 1994

Simognathus gibberosus Bartsch, 1994

Simognathus gracilis Bartsch, 1994

Simognathus maculatus Bartsch, 1994

Simognathus platyaspis Otto, 2000

Simognathus scutatus Bartsch, 1993

Simognathus salebrosus Bartsch, 2003

Simognathus tener Bartsch, 2003

Simognathus uniscutatus Bartsch, 1994

Simognathus variolosus Bartsch, 1994
E, RI

$\mathrm{E}$

RI

E, D

$\mathrm{D}$

RI

RI

$\mathrm{D}$

E, RI

$\mathrm{D}$
$\mathrm{E}, \mathrm{RI}$

D

D

RI

D, RI

$\mathrm{E}$

RI

E

RI

D

$\mathrm{D}$

E

RI

$\mathrm{D}$

RI

$\mathrm{RI}$

E

$\mathrm{RI}$

E, RI

RI

RI

$\mathrm{D}$

RI

D

$\mathrm{D}$

D, E, RI

RI

China

NSW, VIC

QLD

$-$

$-$

QLD

QLD

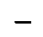

Hawaii, South China Hawaii

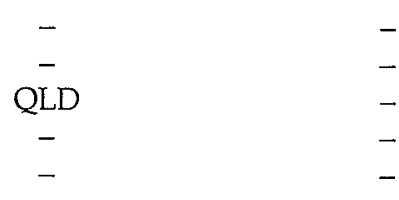

$\begin{array}{cc}- & - \\ - & - \\ - & - \\ - & - \\ - & - \\ \text { QLD } & - \\ - & - \\ - & - \\ - & - \\ - & - \\ - & -\end{array}$

\section{Distribution}

Western Australia, Esperance.

\section{Simognathus gibberosus Bartsch, 1994}

Simognathus gibberosus Bartsch, 1994: 136-140, figures 11-22.

\section{New Material}

Australia: Western Australia: 1 deutonymphal exuvia with a male, WAM T 78344, Esperance,
Duke of Orleans Bay, $33^{\circ} 55^{\prime} \mathrm{S}, 122^{\circ} 35^{\prime} \mathrm{E}$, algal scrub and debris, 19 February 2003.

\section{Supplementary description}

Deutonymph. Dorsal plates small, PD much smaller than in adults; ds-2, ds-3 and ds-4 within striated integument. $\mathrm{AD}$ and $\mathrm{OC}$ with cornea. Ventral plates separate. AE with three pairs of setae, integument smooth within a gable-like area, else foveate. PE with one dorsal and three ventral setae. Genital plate small, with pair of perigenital setae 
and two pairs of internal genital acetabula. Second palpal segment short, with ventral bristle-like seta. All telofemora short, about 1.1 times longer than high. Tibiae I and II short, tibiae III and IV slender. Tarsus II with ventral setae and pair of pas; tarsi III and IV each with one ventral seta and medial pas; lateral pas lacking. Claws II to $I V$ with accessory process.

\section{Remarks}

The deutonymphal exuvia and the male with still soft, unhardened integument and wrinkled legs obviously belong to $S$. gibberosus. The species is characterized by a long $\mathrm{AD}$ that extends almost to the level of the insertion of leg III, large OC, each with a cornea, a gable-shaped area on the $\mathrm{AE}$ that lacks the pits covering the remainder of the plate, a fusion of the ventral plates in males (AE and PE fused with GA but $A E$ and PE separate), the two pairs of outlying setae close to the ring of pgs, a short, slender P-2 with a ventral seta but no apophysis, a cubical tectum with protuberances, the very short telofemora and tibiae, the unusually short but wide spine on tibia I, and the presence of two ventral setae on tarsi III and IV but absence of a pair of pas.

Simognathus gibberosus and the above mentioned $S$. cruciferus are at a first glance strikingly similar, distinguishing characters are: the ornamentation of the $\mathrm{AE}$ (smooth integument in a gable-shaped vs cross-shaped area) and the shape of the P-2 (without vs with ventral protuberans).

\section{Distribution and ecology}

Western Australia, Rottnest Island and Esperance. From shallow waters, from algal turf and sediment.

\section{Simognathus uniscutatus Bartsch, 1994} Figure 12H

Simognathus uniscutatus Bartsch, 1994: 145, figures 45-52.

\section{New Material}

Australia: Western Australia: 1 male, WAM T 78345, Esperance, Lucky Bay, 335' $\mathrm{S}, 122^{\circ} 13^{\prime} \mathrm{E}$, unsorted, medium coarse sediment from about 50 cm water depth, 15 February 2003; 1 female, ZMH, same collecting data.

\section{Supplementary description}

Male. Length of idiosoma $404 \mu \mathrm{m}$. AE and GA fused. Ventral shield foveate, foveation in area representing the AE extending backward just beyond the level of insertion of leg III; foveation on GA reduced to pair of lateral ovate areas (Figure 12H). GO small; 40 setae in a ring close to GO, two pairs outlying. Genital sclerites with three pairs of short sgs.

\section{Remarks}

The female is $335 \mu \mathrm{m}$ long, the male $404 \mu \mathrm{m}$. This is one of the species in which the OC are reduced to narrow sclerites and often obscured by the striated integument, the $\mathrm{AE}$ and GA are fused in both females and males, the second palpal segment has two small ventral protuberances, tibia I has a narrow base and then is abruptly widened, its length, as that of the small tarsus, is about twice the height, the tarsus ends with three claws, the slender paired ones and the large median claw.

Four species in the Australian Simognathus fauna (cf Otto, 2000a; Bartsch, 2003d) have a rather similar character combination, $S$. aspidotus Otto, 2000, $S$. clypeatus Otto, 2000, S. tener Bartsch, 2003 and S. uniscutatus. Simognathus uniscutatus differs from the first three in the number of the ventral setae on tarsi III and IV; in S. uniscutatus there is one ventral seta and a single pas; in the other species one ventral seta and both lateral and medial pas.

\section{Distribution and ecology}

Western Australia, Rottnest Island and Esperance. Psammophilous. All present records are from shallow water areas.

\section{BIOGEOGRAPHICAL REMARKS}

The non-copidognathines to date recorded from the three Western Australian localities Esperance, Rottnest Island and Dampier are summarized in Table 1 with notes on records from in and outside Australia. The data are based on three week stays in each area. The species mentioned by Lohmann (1909) from Geraldton and Shark Bay are not included in the list because of their unverified identity.

More than 40 halacarid species have been collected in shallow water marine habitats of Esperance Bay and surroundings, more than a quarter belongs to the subfamily Copidognathinae, 30 are non-copidognathines. More than 80 halacarid species are recorded from the warm-temperate Rottnest Island, viz. 52 named and another five undescribed or unidentified non-copidognathines and 30 copidognathines, the latter represented by the genera Copidognathus (28 named species), Phacacarus (one species) and Werthella (one species). The tropical Dampier fauna is known to includes 28 species, 25 non-copidognathines and three Copidognathus species. From other regions of Australia, from the the south-eastern and eastern coast, from Victoria, New South Wales and Queensland, slightly more than 100 species are recorded, but this number is incomplete, as that from the tropical Western Australia, as a large part of the halacarid fauna is still undescribed.

The number of non-copidognathines from Esperance is somewhat more than half that 
collected around Rottnest Island. About half of the number of species from Esperance, 16 species or $53 \%$, are shared with the fauna of Rottnest Island, three species, or $10 \%$, are shared with the faunas of Victoria and/or New South Wales. The latter number is much to low as the knowledge of the faunas of those areas is restricted to scattered records of Lohmann (1893), Otto $(1993,1994)$ and Bartsch and Gwyther (2004). In some of the widespread species, individuals from different regions showed small discrepancies in their external morphology, but these assumedly are no evidence for presence of cryptic species. None of the halacarid genera present in the fauna of Esperance is endemic to Australia, all are distributed worldwide. At the species level, 11, more than one-third of the non-copidognathines, are currently not known from outside the Esperance Bay. The number is not evidence for a high halacarid endemicity in this part of Australia, because most of these species are expected to be found outside the south-western coast of Australia once more parts of the Australian coastline are studied thoroughly. Halacarid mites are exclusively benthic, resting or planktonic stages are not known, the fecundity is low, hence they are poor dispersers and slow colonizers (Bartsch, 2004b). Esperance receives water masses from both the western (Leeuwin Current) and eastern (Flinders Current) edge of Australia (Middleton and Cirano, 2002; Cirano and Middleton, 2004), and faunal input of passively transported mites should be possible from both directions. In contrast to the halacarid fauna of southern Australia that of benthic peracarid crustaceans (Tanaidaecea, Isopoda) includes genera not known from outside southern Australia. Of the 21 genera and 26 species of tanaidaceans (Crustacea: Peracarida: Tanaidacea) of Esperance, two genera and 24 species proved to be new to science (Bamber, 2005). Amongst the anthurideans (Crustacea: Peracarida: Isopoda: Anthuridea) two out of 57 genera are known only from southern Australia (Poore, 2001).

Compared with the halacarid fauna of Rottnest Island, that of Esperance is sparse. A reason may be the hydrology and geomorphology of the coast-line. Unpredictable disturbance due to extreme swell and wave action may seriously affect or destroy halacarid populations and the large and finegrained high-energy beaches and swell-exposed almost bare granite rocks (Sanderson et al., 2000; Short, 2006) offer only few habitats for a permanent or temporary colonization and hence stepping stones to isolated or defaunated areas.

\section{ACKNOWLEDGEMENTS}

The material studied was collected during the Twelfth International Marine Biological Workshop held in Esperance, Western Australia. Thanks are due to Fred E. Wells, Fisheries and Marine Research Laboratory, Western Australia, for invitation to take part in the workshop, the other organizers and colleagues who helped in many ways, as also two referees for helpful comments on the manuscript. Travel fundings were provided by the German Research Foundation (DFG).

\section{REFERENCES}

Abé, H. (1997). Halacarid mites of the genus Actacarus (Acari: Halacaridae) from Hokkaido, Northern Japan. Species Diversity 2: 31-42.

Abé, H. and O'Connor, J.P. (1991). A redescription of Scaptognathus trouessarti Halbert, 1915 (Acari, Halacaridae) with notes on some taxonomic characters. Irish Naturalists Journal 23: 436-441.

André, M. (1959). Acari I. Contribution a l'étude des halacariens de la Mer Rouge, In Mission Robert Ph. Dollfus en Égypte. XXVI: 93-119.

Bamber, R.N. (2005). The Tanaidaceans (Arthropoda: Crustacea: Peracarida: Tanaidacea) of Esperance, Western Australia, Australia, In F.E. Wells, D.I. Walker and G.A. Kendrick (eds), Proceedings of the Twelfth International Marine Biological Workshop: The Marine Flora and Fauna of Esperance Western Australia 613-727.

Bartsch, I. (1975). Ein Beitrag zum System der Rhombognathinae (Halacaridae, Acari). Zur Morphologie der Tarsalregion und des Ovipositors. Zoologischer Anzeiger 194: 193-200.

Bartsch, I. (1976). Beitrag zur Halacariden-Fauna (Halacaridae, Acari) der Bretagneküste. Beschreibung von fünf Arten aus dem Sandlückensystem. Acarologia 17: 652-667.

Bartsch, I. (1977a). Ergänzungen zur Halacariden-Fauna (Halacaridae, Acari) der Bretagneküste. Zur Gattung Arhodeoporus und Copidognathus. Acarologia 18: 626-641.

Bartsch, I. (1977b). New species of Lohmannella (Halacaridae, Acari) from the Roscoff area, Brittany. Cahiers de Biologie Marine 18: 141-153.

Bartsch, I. (1977c). Interstitielle Fauna von Galapagos. XX. Halacaridae (Acari). Mikrofauna des Meeresbodens 65: 1-108.

Bartsch, I. (1979a). Halacaridae (Acari) from Oahu Island (Hawaiian Archipelago). Entomologische Mitteilungen aus dem Zoologischen Museum Hamburg 6: 231-241.

Bartsch, I. (1979b). Halacaridae (Acari) aus der Subantarktis. Cahiers de Biologie Marine 20: 325-339.

Bartsch, I. (1981). Halacaridae (Acari) aus dem Kanal von Moçambique. Cahiers de Biologie Marine 22: 35-63.

Bartsch, I. (1985). Zur Halacaridenfauna (Halacaridae, Acari) der Philippinen. Beschreibung von drei neuen Arten. Mitteilungen aus dem Hamburgischen Zoologischen Museum und Institut 82: 269-277.

Bartsch, I. (1986). New species of Halacaridae (Acari) from New Zealand. New Zealand Journal of Zoology 12: $175-185$. 
Bartsch, I. (1988). Arenicolous Halacaridae (Acari) in Hawaiian waters. Proceedings, Hawaiian Entomological Society 28: 213-228.

Bartsch, I. (1991). Arhodeoporus mactanus n. sp., a new species of marine mite (Acari, Halacaridae), from the Philippines. The Philippine Journal of Science 120: 21-25.

Bartsch, I. (1992a). Lohmannella dictyota n. sp. und $L$. africana n. sp. von der Südhalbkugel (Arachnida: Acari: Halacaridae). Senckenbergiana Biologica 72 : 457-464.

Bartsch, I. (1992b). Two new species of the genus Bradyagaue (Halacaridae, Acari) from the Southern Indian Ocean. Cahiers de Biologie Marine 33: 433440.

Bartsch, I. (1993a). Synopsis of the Antarctic Halacaroidea (Acari). Synopses of the Antarctic Benthos 4: 1-176.

Bartsch, I. (1993b). Rhombognathine mites (Halacaridae, Acari) from Rottnest Island, Western Australia, In F.E. Wells, D.I. Walker, H. Kirkman and R. Lethbridge (eds), Proceedings of the Fifth International Marine Biological Workshop: The Marine Flora and Fauna of Rottnest Island, Western Australia: 19-43.

Bartsch, I. (1993c). Halacarus (Halacaridae, Acari) from south-western Australia, In F.E. Wells, D.I. Walker, H. Kirkman and R. Lethbridge (eds), Proceedings of the Fifth International Marine Biological Workshop: The Marine Flora and Fauna of Rottnest Island, Western Australia 1: 45-71.

Bartsch, I. (1993d). Arenicolous Halacaridae (Acari) from Rottnest Island, Western Australia, In F.E. Wells, D.I. Walker, H. Kirkman and R. Lethbridge (eds), Proceedings of the Fifth International Marine Biological Workshop: The Marine Flora and Fauna of Rottnest Island, Western Australia 73-103.

Bartsch, I. (1994). The genus Simognathus (Acari, Halacaridae), description of six new species from southern Australia and a tabular key to all species. Acarologia 35: 135-152.

Bartsch, I. (1996a). New records of Actacarus from the Caribbean area, and notes on the subfamily Actacarinae and its species (Arachnida: Acari: Halacaridae). Senckenbergiana Biologica 75: 229-241.

Bartsch, I. (1996b). Halacarines (Acari: Halacaridae) from Rottnest Island, Western Australia: the genera Agauopsis Viets and Halacaropsis gen. nov. Records of the Western Australian Museum 18: 1-18.

Bartsch, I. (1997). Arhodeoporus (Acari: Halacaridae) from Rottnest Island, description of three new species. Acarologia 38: 265-274.

Bartsch, I. (1998). Halacarinae (Acari, Halacaroidea) from the northeastern Black Sea. A review. Mitteilungen aus dem Hamburgischen Zoologischen Museum und Institut 95: 143-178.

Bartsch, I. (1999a). Actacarus ponticus, a new marine mite from the Black Sea (Arachnida, Acari, Halacaridae). Senckenbergiana Biologica 78: 141-151.

Bartsch, I. (1999b). Wiederbeschreibung zweier Arten der Agauopsis ornata-Gruppe (Acari, Halacaridae). Entomologische Mitteilungen aus dem Zoologischen Museum Hamburg 13: 37-48.

Bartsch, I. (1999c). Halacaridae (Acari) from Rottnest
Island, Western Autralia. Mites on fronds of the seagrass Amphibolis, In D.I. Walker and F.E. Wells (eds), Proceedings of the Ninth International Marine Biological Workshop: The Seagrass Flora and Fauna of Rottnest Island, Western Australia 333-357.

Bartsch, I. (1999d). Halacaridae (Acari) from Rottnest Island: Description of two Agaue species. Acarologia 40: $179-190$.

Bartsch, I. (2000). Rhombognathinae (Acari: Halacaridae) from the Great Barrier Reef, Australia. Memoirs of the Queensland Museum 45: 165-203.

Bartsch, I. (2003a). The subfamily Rhombognathinae: developmental pattern and re-evaluation of the phylogeny (Arachnida, Acari, Halacaridae). Senckenbergiana Biologica 82: 15-57.

Bartsch, I. (2003b). Halacarus ctenopus Gosse, 1855 (Acari, Halacaridae), description of the neotype. Acarologia 43: 223-28.

Bartsch, I. (2003c). Rhombognathine mites (Halacaridae: Acari) from Dampier, Western Australia: taxonomy and biogeography, In F. E. Wells, D. I. Walker and D. Jones (eds), Proceedings of the Eleventh International Marine Biological Workshop: The Marine Flora and Fauna of Dampier; Western Australia 255-280.

Bartsch, I. (2003d). Psammophilous halacarids (Halacaridae, Acari) from Dampier, Western Australia. Description of species and faunal comparison of the mesopsammal halacarid fauna of western and eastern Australia. Records of the Western Australian Museum 22: 23-45.

Bartsch, I. (2004a). Bradyagaue from Western Australia, description of a new species (Acari, Halacaridae). Cahiers de Biologie Marine 45: 65-69.

Bartsch, I. (2004b). Geographical and ecological distribution of marine genera and species (Acari: Halacaridae). Experimental and Applied Acarology 34: 37-58.

Bartsch, I: (2005a). Halacaridae from the depths of Western Antarctica (Arachnida: Acari). Senckenbergiana Biologica 85: 31-41.

Bartsch, I. (2005b). Lohmannella and Simognathus (Halacaridae: Acari) from Western Australia: description of two new species and reflections on the distribution of these genera. Records of the Western Australian Museum 22: 293-307.

Bartsch, I. (2005c). The Australian Agauopsis fauna (Halacaridae: Acari), with description of new and known species of Western Australia, In F.E. Wells, D.I. Walker and G.A. Kendrick (eds), Proceedings of the Twelfth International Marine Biological Workshop: The Marine Flora and Fauna of Esperance, Western Australia: 343-362.

Bartsch, I. (2005d). Western Australian Werthella (Copidognathinae: Halacaridae: Acari), description of a new and notes on related species, In F.E. Wells, D.I. Walker and G.A. Kendrick (eds), Proceedings of the Twelfth International Marine Biological Workshop: The Marine Flora and Fauna of Esperance, Western Australia: 363-373.

Bartsch, I. (2005e). The rhombognathine fauna of Australia (Rhombognathinae: Halacaridae: Acari) with notes on the fauna of Esperance, Western Australia, In F.E. Wells, D.I. Walker and G.A. 
Kendrick (eds), Proceedings of the Twelfth International Marine Biological Workshop: The Marine Flora and Fauna of Esperance, Western Australia: 375-397.

Bartsch, I. and Iliffe, T. (1985). The halacarid fauna Halacaridae, Acari) of Bermuda's caves. Stygologia 1: 300-321.

Bartsch, I. and Gwyther, J. (2004). A non-indigenous halacarid species in Victoria, southeastern Australia, Isobactrus uniscutatus (Rhombognathinae, Halacaridae, Acari). Proceedings of the Royal Society of Victoria 116: 201-206.

Cirano, M. and Middleton, J.F. (2004). Aspects of the mean wintertime circulation along Australia's southern shelves: numerical studies. Journal of Physical Oceanography 34: 668-684.

Gimbel, O. (1919). Über einige neue Halacariden. Mitteilungen aus dem Zoologischen Museum in Hamburg 36: 106-130.

Green, J. and MacQuitty, M. (1987). Halacarid Mites. Synopsis of the British Fauna (New Series) 36: 178pp.

Gosse, P. H. (1855). Notes on some new and little-known marine animals. The Annals and Magazine of Natural History, London, Second Series 16: 27-36.

Halbert, J.N. (1915). Clare Island Survey. Acarinida. Section II. - Terrestrial and marine Acarina. Proceedings of the Royal Irish Academy 31: 45-136.

Kendrick, G., Harvey, E., McDonald, J., Wells, F. and Walker, D. (2005). Introduction to the marine biology of the Esperance region of Western Australia, In F.E. Wells, D.I. Walker and G.A. Kendrick (eds) Proceedings of the Twelfth International Marine Biological Workshop: The Marine Flora and Fauna of Esperance, Western Australia: 1-9.

Knox, G.A. (1963). The biogeography and intertidal ecology of the Australasian coast. Oceanography and marine Biology. Annual Review 1: 341-404.

Konnerth-Ionescu, A. (1977). Marine Acari (Arachnida, Acari) from the littoral waters of Tanzania. Travaux du Muséum d'Histoire Naturelle Grigore Antipa 18: $67-71$.

Li, Q., James, N.P., Bone, Y. and McGowran, B. (1999). Palaeoceanographic significance of recent foraminiferal biofacies on the southern shelf of Western Australia: a preliminary study. Palaeogeography, Palaeoclimatology, Palaeoecology 147: 101-120.

Lohmann, H. (1889): Die Unterfamilie der Halacaridae Murr. und die Meeresmilben der Ostsee. Zoologische Jahrbücher, Abteilung Systematik, Ökologie und Geographie der Tiere 4: 269-408.

Lohmann, H. (1893). Die Halacarinen der PlanktonExpedition. Ergebnisse der Plankton-Expedition der Humboldt-Stiftung 2: 11-95.

Lohmann, H. (1907). Die Meeresmilben der Deutschen Südpolar-Expedition 1901-1903. Deutsche Südpolar Expedition 1901-1903 9: 361-413.

Lohmann, H. (1909). Marine Hydrachnidae und Halacaridae, In W. Michaelsen and R. Hartmeyer (eds), Die Fauna Südwestaustraliens. Ergebnisse der Hamburger Südwest-australischen Forschungsreise 1905 2: 149-154.
Makarova, N.G. (1977). Marine mites (Acarina: Halacaridae) of the intertidal zone of the Kurile Islands, In V.V Gulbin, M.B. Ivanova, O.G. Kussakin and T.F. Tarakanova (eds) Fauna Pribreznich Zon Kurilskich Ostrovov: 125-142 (in Russian).

Middleton, J.F. and Cirano, M. (2002). A northern boundary current along Australia's southern shelves: The Flinders Current. Journal of Geophysical Research/Ocean 107, C9: 12-1-12-11

Morselli, I. and Mari, M. (1986). Researches on the coast of Somalia. The shore and the dune of Sar Uanle. 39. On three interstitial species of Halacaridae (Acari). Monitore Zoologico Italiano, n.s. supplemento 21: 137-148.

Newell, I.M. (1947). A systematic and ecological study of the Halacaridae of eastern North America. Bulletin of the Bingham Oceanographic Collection 10: 1-232.

Newell, I.M. (1971). Halacaridae (Acari) collected during cruise 17 of the $R / V$ Anton Bruun, in the southeastern Pacific Ocean. Anton Bruun Report 8: 3-58.

Newell, I.M. (1984). Antarctic Halacaroidea. Antarctic Research Series 40: 1-284.

O'Hara, T.D. and Poore, G.C.B. (2000). Patterns of distribution for southern Australian marine echinoderms and decapods. Journal of Biogeography 27: 1321-1335.

Otto, J.C. (1993). Description of a new species of the Agauopsis hirsuta-group from Australia (Acarina : Halacaridae). Acarologia 34: 211-221.

Otto, J.C. (1994). New species of Halacaridae from Australia (Acarina : Prostigmata). Acarologia 35: 3148.

Otto, J.C. (1999). Halacarid fauna of the Great Barrier Reef and Coral Sea: the genera Agauopsis and Halacaropsis (Acarina: Halacaridae). Memoirs of the Queensland Museum 43: 797-817.

Otto, J.C. (2000a). Simognathinae (Acarina: Halacaridae) from the Great Barrier Reef and Coral Sea, description of thirteen new species. Memoirs of the Queensland Museum 45: 505-534.

Otto, J.C. (2000b). Halacaridae from the Great Barrier Reef and Coral Sea: the genera Lohmannella, Scaptognathides and Scaptognathus (Acarina: Halacaridae: Lohmannellinae). Memoirs of the Queensland Museum 45: 535-555.

Otto, J.C. (2000c). Acarochelopodia and Actacarus species (Acari: Halacaridae) from Australia, with remarks on $A$. pacificus and A. orthotectus. Species Diversity 5: $111-127$.

Otto, J.C. (2000d). Seven new species of Arhodeoporus (Acarina: Halacaridae) from the Great Barrier Reef and Coral Sea. Hydrobiologia 436: 1-16.

Otto, J.C. (2001). Halacaridae of the Great Barrier Reef Lagoon and Coral Sea: Halacarellus and Halacarus. (Acarina: Halacaroidea). Memoirs of the Queensland Museum 46: 691-716.

Poore, G.C.B. (2001). Families and genera of Isopoda Anthuridae, In B. Kensley and R.C. Brusca (eds) Isopod Systematics and Evolution, Crustacean Issues 13: 63-173.

Sanderson, P.G., Eliot, I., Hegge, B. and Maxwell, S. (2000). Regional variation of coastal morphology in 
southwestern Australia: a synthesis. Geomorphology 34: 73-88.

Sarma, A.L.N. and Chatterjee, T. (1993a). Record of Atelopsalis pacifica Bartsch 1985 (Halacaridae: Acari) from eastern Indian Ocean. Journal of the Bombay Natural History Society 90: 117-119.

Sarma, A.L.N. and Chatterjee, T. (1993b). Occurence of Arhodeoporus bonairensis (Viets, 1936) (Halacaridae: Acari) from Indian Ocean with zoogeographical remarks on the genus Arhodeoporus Newell. Journal of the Bombay Natural History Society 90: 417-422.

Schulz, H. (1937). Actacarus pygmaeus n.g. n. sp., eine merkwürdige Meeresmilbe aus der Otoplanen-Zone der Nordsee. Kieler Meeresforschungen 1: 327-331.

Short, A.D. (2006). Australian beach systems - nature and distribution. Journal of Coastal Research 22: 11-27.

Trouessart, E.L. (1888). Note sur les acariens marins recueillis par M. Giard au laboratoire maritime de Wimereux. Compte rendu de l'Académie des Sciences, Paris 107: 753-755.

Trouessart, E.L. (1889a). Sur les acariens marins des côtes de France. Compte rendu de I'Académie des Sciences, Paris 108: 1178-1181.

Trouessart, E.L. (1889b). Revue synoptique de la famille des Halacaridae. Bulletin scientifique de la France et de la Belgique (série 3) 20: 225-251.

Trouessart, E.L. (1896). Halacariens. Résultats scientifiques de la Campagne du CAUDAN dans le Golf de Gascogne. Annales de l'Université de Lyon 26: 325-353.

Trouessart, E.L. (1901). Note sur les acariens marins (Halacaridae) récoltés par $M$. Henri Gadeau de Kerville dans la région d'Omonville-la-Rouge (Manche) et dans la fosse de la Hague (Juin-Juillet 1899). Bulletin de la Société des amis des sciences naturelles de Rouen (Série 4) 14: 247-266.
Viets, K. (1927). Die Halacaridae der Nordsee. Zeitschrift für wissenschaftliche Zoologie 130: 83-173.

Viets, K. (1935). IV.-Some marine mites from Alexandria, In The Fishery Grounds near Alexandria. Fishery Research Directorate Coastguard and Fisheries Service 1-4.

Viets, K. (1936). Zoologische Ergebnisse einer Reise nach Bonaire, Curaçao und Aruba im Jahre 1930. No. 18. Halacariden aus Westindien. Zoologische Jahrbücher für Systematik, Ökologie und Geographie der Tiere 67: 389-424.

Viets, K. (1940). Meeresmilben aus der Adria (Halacaridae und Hydrachnellae, Acari). Archiv für Naturgeschichte (Neue Folge) 9: 1-135.

Viets, K. (1950). Die Meeresmilben (Halacaridae, Acari) der Fauna Antarctica. Further Zoological Results of the Swedish Antarctic Expedition 1901-1903, 4 (3): 144.

Wells, F.E. Longbottom, A.F., Longbottom, J. (2005). The marine molluscs of Esperance Bay and the Recherche Archipelago, Western Australia, In F.E. Wells, D.I. Walker and G.A. Kendrick (eds) Proceedings of the Twelfth International Marine Biological Workshop: The Marine Flora and Fauna of Esperance, Western Australia: 289-313.

Womersley, H. (1937). Acarina. Australasian Antarctic Expedition 1911-1914, Scientific Reports, Series C, 10(6): 1-24. 